\begin{tabular}{|c|c|c|c|}
\hline \multirow{2}{*}{ A } & \multicolumn{3}{|c|}{$\begin{array}{l}\text { ADIYAMAN ÜNIVERSITESI SOSYAL BiLIMLER ENSTITÜSÜ DERGISi } \\
\text { ISSN: 1308-9196 }\end{array}$} \\
\hline & YIl : 5 & Sayı : 10 & Aralık 2012 \\
\hline
\end{tabular}

\title{
ÇEVRE HUKUKUNUN ULUSAL VE ULUSLARARASI BOYUTLARI
}

\author{
Şafak KAYPAK ${ }^{*}$
}

\begin{abstract}
Öz
Bu çalışma, çevre hukukunun ulusal ve uluslararası boyutlarını inceleme amacını taşımaktadır. Günümüzde, çevre sorunları tüm canlıları tehdit etmektedir. Bunun nedeni, uygulanan sosyal ve ekonomik politikalardır. Çevre sorununun asıl çıkış yeri yerel olsa da, çözümü ancak ulusal ve uluslararası düzeyde olabilmektedir. Ulusal düzeyde ortaya çıkan bir çevre sorununun çözümü, sorunun başka ülkeleri etkilemesi durumunda yetersiz kalabilmektedir. Bu yüzden, ülkeler arasında çevre sorunlarına çözüm bulma girişimleri, çevre hukuku adında yeni bir hukuk dalının doğmasına yol açmıştır. Bu bağlamda, çalışma çevre hukukunun gelişimi, ulusal ve uluslararası boyutları üzerine odaklanmaktadır.
\end{abstract}

Anahtar Kelimeler: Çevre, hukuk, çevre hukuku, ulusal ve uluslararası çevre hukuku.

\section{NATIONAL AND INTERNATIONAL DIMENTIONS OF ENVIRONMENTAL LAW}

\begin{abstract}
This study is intended to examine the national and international dimensions of environmental law. Today environmental problems threaten all living things. The cause of the problems is the social and economic policies implemented. Despite the fact that the real problem is local, the solution seems national and international. Solution of an environmental problem that emerged at the national level, if the problem affects other countries may be insufficient. Therefore, efforts to find solutions for environmental problems between countries led to emergence of a new discipline named environmental law. In this context, study focuses on the national and international dimensions and development of environmental law.
\end{abstract}

Key Words: Environment, law, environmental law, national and international environmental law.

\footnotetext{
${ }^{*}$ Yrd.Doç.Dr., Mustafa Kemal Üniversitesi, İktisadi ve İdari Bilimler Fakültesi, Kamu Yönetimi Bölümü, skaypak@gmail.com
} 


\section{GiRiş}

İnsan doğada var oluşundan bu yana çevresinden mümkün olduğunca yararlanmıştır. Bilimin olanaklarıyla kendini yeterince güçlü gördüğünde, doğayı sınırsızca kullanmaya başlamış ve uzun süre doğaya zarar verdiğini fark etmemiştir. Çevrenin kullanılması herhangi bir özveri gerektirmemesi nedeniyle, bir çeşit serbest veya herkesin kullanabileceği ortak mal olarak değerlendirilmiştir. Bugün ise, çevre kaynakları birçok yerde giderek kıtlaşan ve arzı talebinden az olan ekonomik bir mal veya geri dönüşü olmayan bir değer haline gelmiştir.

Günümüzde çevre sorunlarının salt yerel bir sorun olmadı̆̆ı; aksine bütün toplumları etkileyen küresel bir sorun olduğu gerçeği anlaşılmış bulunmaktadır. Ancak, bu noktaya gelinceye kadar, çevreye ilişkin sorunlar, birikerek, ülkelerin tek başlarına çözemeyecekleri kadar büyümüş ve daha karmaşık bir hale gelmiştir. Çevrenin korunması ve çevre kirliliği sorunu, kirliliğin kaynağı olan ülke ile sınırlı kalmamakta, dünya üzerinde var olan diğer devletleri ve insanları da etkilemektedir. Sorunların büyüklüğü ve karmaşıklığı, ulusal ve uluslararası boyutta yeniden yapılanmayı, işbirliğini ve yaptırımlı olmayı zorunlu kılmaktadır. Sağlıklı bir yaşamın sürdürülmesi, ancak sağlıklı bir çevre ile mümkün olduğundan, çevreye ilişkin düzenleme yapmak bir gereklilik olmuştur. Çevreye ilişkin düzenlemeler denince, insanın doğal ve yapay yaşam alanının gelişimi, bakımı ve korunmasını sağlayacak düzenlemeler anlaşılmaktadır. Şimdiki ve gelecek kuşaklar için, kısa dönemli düzenlemeler yerine; uzun dönemli, küresel ve bütün insanlık için en az risk taşıyan düzenlemelere gitmek, dünyanın ve insanlığın geleceği açısından zorunlu olmaktadır. Bu zorunlulukların sonucunda, yeni örgütlenmelere ve hukuki düzenlemelere ilişkin çalışmalar giderek daha sık yapılmaktadır. Çevre için en önemli gelişme, sorunlara yönelik çözümleri hukuksal bir zemine oturtma çalışmalarının olmasıdır. Ulusal ve uluslararası alanda, devletler ve kuruluşların çevreye ilişkin sorunların çözümüne yönelik olarak yapmış oldukları çalışmalar doğrultusunda çevre hukuku adı verilen yeni bir disiplin dalı oluşmaya başlamıştır. 
Bu çalışmada, çevre hukukunun ortaya çıkış nedenleri ve ulusal boyuttan uluslararası boyuta yansıma şekli irdelenmektedir. Bu çalışmanın hipotezi, çevre sorunlarının küresel nitelikte hukuksal bir sorun olduğudur. Bu bağlamda, çalışma dört bölümden oluşmaktadır. İlk bölümde, çevre ve çevre sorunları ele alınacaktır. İkinci bölümde, çevre hukuku ve ulusal boyutları üzerinde durulacaktır. Üçüncü bölümde ise, uluslararası çevre hukuku ile ilgili konulara değinilmektedir. Son bölüm, sonuç ve değerlendirmeyi içermektedir.

\section{2. ÇEVRE VE ÇEVRE SORUNLARI}

Çevre Türkçe bir sözcüktür. Ortam, kenar, etraf, civar, mıntıka, bölge, durum veya çember gibi karşılıklara da gelmektedir. Çevre sözcüğü ilk kullanılmaya başlandığı yıllarda, "dolaylarında", "bulunulan yerin civarı" gibi dar bir anlamda, yakın fiziksel çevreyi kastederek kullanılmıştır. Daha sonraki yıllarda, çevrenin sadece mekan olmadığı anlaşılmıştır. Öneminin artmasını ve farklı bakış açılarını takip ederek sözcüğün içeriği genişlemiş ve daha geniş bir içerikle kullanılmaya başlanmıştır (Keleş ve Hamamcı, 1993: 22). Çevre kavramına fiziksel niteliklerin yanı sıra, sosyal, kültürel, ekonomik, psikolojik, siyasal içerikler de eklenmiştir.

Öyle ise, çevre nedir sorusuna dar ve geniş anlamda karşılık verebiliriz: Çevre en dar anlamda, bulunulan yerdir. Canlılar için bulundukları, yaşadıkları ortamdır. Yani başka bir ifade ile "habitat"larıdır. En geniş anlamda çevre, yaşam için uygun koşulların varolduğu "biyosfer"-canlı küredir. Çevre sözcüğü günlük yaşamda en fazla kullandığımız kavramlardandır. Çünkü, çevre değişkendir ve sınırları esnektir. Her bilim dalı, çevreye kendi bakış açısına göre bakmaktadır. Farklı bakış açılarına göre, çevre hem içinde bulunulan ortam; hem de ortamdakileri etkileyen etken olarak görülebilmektedir. Ayrıca, günlük kullanımda bu sözcüğü kullanan kimse çevreyi nasıl görmek istiyorsa, o anlama gelebilmekte, o anlama bürünebilmektedir. Örneğin, her insanın kendisine göre bir çevre anlayışı ve bir çevresi söz konusudur: Aile çevresi, 
arkadaş çevresi, iş çevresi, kentsel çevre, nüfuz çevresi vb. Kavram, içine konulan sıvıya göre şekillenen bir tas gibidir. Zira, çevre kendi başına değil, bir şeye göre belirlenmekte ve kastedilen çevre de o şeyin dışındaki, o şeyi sınırlayan veya saran ortam olmaktadır. Çevre, buradaki anlamında sınırları çizen, belirleyendir. Yani bir çevrelenen, bir de çevreleyen vardır. Çevrelenen merkezde, çevreleyen ise, onun etrafındadır. Merkezde aktif olarak yeralan özne veya nesne, onu kuşatan çevreyle karşılıklı etkileşim içindedir. Bu nedenle, çevre kavram olarak aktif değil, pasif bir içeriğe sahiptir. Soyuttur. Adresi verildiğinde ve üzerinde işlem veya faaliyet yapıldığında somutlaşır (Kaypak, 2009:8).

O zaman, çevre dendiğinde hangi çevreyi anlamak gerekir? Çevre bireyin dışındaki her şey olarak tanımlanmaktadır artık. Bu tanım, hem doğal ve yapay çevreyi; hem de toplumsal ve kültürel çevreyi içine alır. Böyle bakıldığında, çevrenin kapsamadığı hiçbir alan ve süreç kalmamaktadır. Bu durumda, çevre, doğal kaynakları da içeren, işlenmiş ve işlenmemiş, yapılanmış ve yapılanmamış, doğal ve maddi kültür öğelerinin birlikte oluşturduğu bir ortamdır. Dünya genelinden bakılırsa tek bir çevre söz konusudur: o da yaşadığımız dünyadır. Merkezde insanın yeraldığını düşünerek çevreyi; canlı varlıklar üzerinde dolaylı ya da dolaysız bir etkide bulunabilecek fiziksel, kimyasal, biyolojik ve toplumsal etkenlerin belirli bir zamandaki toplamını oluşturan ortam ve koşullar diye tanımlayabiliriz (Keleş ve Hamamcı, 1993: 22). Çevre Yasası çevreyi; "canlıların yaşamları boyunca ilişkilerini sürdürdükleri ve karşılıklı olarak etkileşim içinde bulundukları biyolojik, fiziksel, sosyal, ekonomik ve kültürel ortam" diye tanımlayarak aynı şekilde görmektedir (Çevre Kanunu md. 2).

Sorun sözcüğü de, yine çevre gibi günlük yaşamda çok kullandığımız kavramlardan sayılır. Sorun, bir sistemde veya bir kişide gerginlik oluşturan, giderilmediği takdirde sistemin işleyişini zora sokan, huzursuzluk veren duruma denmektedir. Sorun denildiğinde çağrışım yapan olumsuzluk durumudur: açmaz, çıkmaz, sıkıntı, zorluktur. Sorun, içeriğiyle aktif, ama itici bir durum ve negatif bir algılama olarak karşımıza 
çıkmaktadır. Sorun, hedefleri engelleyen ve normal olmayan, çözüm gerektiren, çözümlendiğinde rahatlatan bir durumdur (Kaypak, 2009:9). Bu durumda, çevre sorunu, canlı ve cansız varlıkların karşılıklı etkileşimleri sonucu oluşan ve sistemin işleyişini zorlaştıran ve çalışamaz duruma sokan düzensizlik halidir (Şahin:2004:432). Ama, mutlaka çözüm bekleyen, bir sonuca bağlanması gereken; doğru yöntemle çözülmediğinde ise, daha da ağırlaşabilecek bir durumdur. Çevre sorunları; çevreyi oluşturan canlı ve cansız unsurlar üzerinde, insanın çeşitli faaliyetlerine bağlı olarak ortaya çıkan ve yaşamı olumsuz yönde etkileyen, bozulmaların ve sorunların tümüdür. Doğanın temel fiziksel unsurları olan hava, toprak ve su üzerinde zararlı etkilerin oluşması ile ortaya çıkan ve canlıların hayati faaliyetlerini olumsuz yönde etkileyen çevre sorunlarının tümü çevre kirliliğini meydana getirmektedir (Çevre Kanunu md. 2). Çevre kirliliği, doğanın kendini temizleme gücünün üstünde olan yüklerin çevrede meydana getirdiği birikimlerdir. Çevre sorunları, insan faaliyetleri sonucu oluşan, istenmeyen veya zarara neden olan değişmeler biçiminde algılandığına göre, bir çeşit dış etki olarak da adlandırılabilir. Öyleyse çevre sorunlarında iki boyut gizlenmektedir. İlki hava ve suyun kirlenmesi gibi nesnel boyut ve bu nesnel durumu kişi ve kişilerin algılaması ile ilgili öznel boyut (Ünder, 1996:1). Bu durum, neyin çevre sorunu olarak değerlendirilebileceği konusunda düşünce farklılığını da beraberinde getirmektedir. Çünkü bir kişinin sorun olarak algıladığını, başka biri sorun olarak görmeyebilir veya birinin önemli gördüğünü, başkası önemsiz olarak nitelendirebilir. Ya da bu sorunu çözüm yolları farklı olabilir. Genelde herkes tarafından açık ve net bir şekilde görünen nesnel boyut, sorun değerlendirmesinde ve çevre standartlarının oluşturulmasında daha önde gelmektedir.

Yaşamımızı sürdürdüğümüz çevre içinde, önce azar azar hissedilen, sonra giderek yoğunlaşan ve gelecekteki yaşamları etkileyebilecek duruma gelen çevre sorunları ortaya çıkmıştır. İnsanların yapay çevrelerini oluşturmak ve bu çevredeki yaşamlarını sürdürmek için doğal kaynakları yok edercesine kullanıp sömürmeleri, zaman içinde, değişik etkenlerin de eklenmesiyle bugünkü boyutlarına ulaşmıştır. Çevreyi oluşturan 
temel unsurlardan hava, su ve toprakta, doğal koşullarda çevreyle ilgili bir denge ve biyosferde çok yönlü, karşılıklı bir etkileşim bulunmaktadır. Bir ilişkiler sistemi olan çevrenin bozulması ve sorunlaşması, genellikle insan kaynaklı etkilerin doğal dengeleri bozmasıyla başlamıştır. Doğal ve yapay çevrenin ortak kesişme noktasında yer alan insan, doğayı kirleten ve ekolojik dengeyi bozan başlıca etkendir. İnsanın çevresiyle oluşturduğu doğal dengeyi meydana getiren zincirin halkalarında meydana gelen kopmalar, zincirin tümünü etkileyip, ekolojik dengenin bozulmasına neden olmakta ve çevre sorunlarını oluşturmaktadır (Kaypak, 2008:187). Bu nedenle, bu ortamlardan herhangi birinde meydana gelen kirlenme, diğerlerine de taşınmakta ve zararlı olabilmektedir. Kirlenme sınır tanımamakta, sadece oluştuğu alanı değil, kilometrelerce uzaktaki ortamları da etkilemektedir.

Çevre sorunları sanayileşmenin doğurduğu olumsuz sonuçlardan biridir. Özellikle Sanayi Devriminin "Sanayi Toplumu”nu ortaya çıkarması, birçok sorunu da beraberinde getirmiştir. Sanayi devrimiyle birlikte üretim unsuru olarak algılanmaya başlayan çevre, sanayileşme sürecinde çok yoğun biçimde üretime katılmıştır. Çevrenin bir üretim unsuru olarak görülüp bu şekilde kullanılması, başta kirlilik olmak üzere çeşitli çevre sorunlarına neden olmuştur. Sadece kâra odaklı ekonomik kalkınma modelinin bir yansıması ve sonucu olarak, doğal varlıklar tükenmeye, kirlenmeye başlamıştır. Üretim ilişkileri, üretim araçlarının kullanımı ve mülkiyeti, sanayileşme, kentleşme, nüfus, göç, yoksulluk, barınma, açlık çevre sorunlarını oluşturan ya da tetikleyen olgulardır. Özellikle 20. yüzyılda yaşanan teknolojik gelişmelerin sanayileşmeyi hızlandırması çevre sorunlarının da artmasına neden olmuştur. Çevre sorunları sürekli artış göstermesine karşın, çevreye verilen bu zararlar doğanın kendini yenileyebilme özelliği nedeniyle başlangıçta önemsenmemiş, çevrenin zamanla bu kirliliği yok edeceği düşünülmüştür. Normal koşullarda kendi kendini temizleme özelliği olan doğa, insanların çeşitli faaliyetleri sonucunda aşırı derecede kirlenmiş ve kendi gücünü aşan bu kirlenmeyi temizleyemez hale gelmiştir. Ayrıca, sorumlu kişi, kurum ve ülkeler tarafından da sorun uzun bir süre zararsız gösterilmiş ya da göz ardı edilmiştir. Zaman içinde çevreye 
bırakılan kirliliğin nicel ve nitel olarak artması; metal ve radyasyon gibi ayrıştırılamayacak olanların katılması ile çevre kendini yenileyebilme özelliğinin çok üstüne çıkmış ve hızla bozulmaya başlamıştır (Görmez, 1997: 12-15). Bu yaklaşımların sonucunda, tıpkı insan gibi pek çok canlının varlığı tehlikeye girmiş ve sorunun çözümü çok daha zor ve karmaşık hale gelmiştir. Hızlı teknolojik gelişme ile birlikte, nüfus artışının, kentleşmenin ve sanayileşmenin doğa üzerindeki baskısı had safhaya ulaşmıştır.

Gelişmiş ve gelişmekte olan ülkelerde çevre sorunlarının ortaya çıkış biçimleri, nedenleri ve etkileri farklı olmaktadır. Gelişmiş ülkelerdeki çevre sorunlarını üretim teknolojisi ile tüketim belirlemektedir. Bu ülkeler gelişme düzeyleri nedeniyle doğal kaynak talepleri arttığı için daha çok kaynak kullanıp çevrenin daha çok kirlenmesine neden olmaktadır. Gelişmiş ülkelerde üretim ve tüketim artışından doğan bir bolluk kirlenmesinden; gelişmekte olan ülkelerde ise yoksulluk kirlenmesinden söz edilmektedir. Özellikle, 1950'lerden sonra gelişmiş ülkelerin yolundan gitmek; kısa vadede ekonomik büyüme ve kalkınma hedefine ulaşmak isteyen gelişmekte olan ülkeler önceliği çevreye değil, ekonomiye vermek istemektedirler. Ama nüfus artışı fazla olduğundan oluşturulmak istenen ekonomik altyapılar yetersiz kalmaktadır. Gelişmiş ve gelişmekte olan ülkeler arasında çevre kirliliğinin oluşumu yönünden gözlenen diğer önemli farklılık, gelişmiş ülkelerin gelişmekte olan ülkelere çevre kirliliğini ihraç etme eğiliminde olmaları ile ortaya çıkmaktadır. Gelişmiş ülkeler yardım adı altında az gelişmiş ülkelerde kirletici sanayiler kurmakta ve öteden beri yatırım adı altında bu ülkelerin kaynaklarını kullanmaktadırlar (Keleş ve Hamamcı, 1993: 32). Ayrıca, gelişmiş ülkelerin sanayi atıkları için üçüncü dünya ülkelerini veya uluslararası suları seçtikleri de bilinen bir gerçektir (Jardıns, 2006:436).

Günümüzde, çevre sorunları, insanı kendi kendisiyle hesaplaşma noktasına getiren bir boyuta ulaşmıştır. Sanayi atıklarının çevre üzerindeki olumsuz etkileri insan ve çevre sağlığını tehdit etmeye başlamış, ozon tabakasının incelmesi ve iklim değişiklikleri, 
küresel ısınma ve sera etkisi, buzulların erimekte olması, kuraklık ve çölleşme, içme suyu kaynaklarının azalması bunlara bağlı olarak beslenme sorunları, kanser ve benzeri hastalıkların artması şeklinde gözardı edilemeyecek tehlikeli boyutlara ulaşmıştır. Deprem, olağandışı yağmurlar, sel, kasırga gibi doğal afetlerin artması, bölgesel savaşlar, kitlesel terör faaliyetleri, canlı insan, hayvan, bitki ve organ kaçakçılığı, sınıraşırı çevre suçları, radyasyon ve baz istasyonlarıyla ilgili elektromanyetik ve GDO'lu ürünlerle ilgili transgenik kirlilik, biyogüvenlik vb. dünyamızın son yıllardaki en önemli çevre sorunlarını oluşturmaktadır. Bu sorunlara acilen çözüm getirilmezse çok yakın bir zamanda dünyamız, uzaydan da düşenlerle birlikte büyük bir çöplüğe dönüşecektir. İçinde bulunduğumuz yüzyıl; birçok teknolojik olanağı insanlığın hizmetine sunarken, bir yandan da insanlığın ortak malı olan çevreden geri getirilmesi zor, hatta olanaksız olan varlıkları da alıp götürmektedir. Ülkemizde de, sorunların çevre için sürekli bir dışsalıı yarattığı görülmektedir. Bu durum, ülkemizin bugün olduğu kadar, gelecekte de çevre sorunları ile karşılaşacağının bir göstergesidir.

\section{3. ÇEVRE HUKUKU VE ULUSAL BOYUTLARI}

Toplum her isteyenin her istediğini yaptığı bir yer değildir. Toplum yaşamında bir düzen vardır. Düzen, belirli bir toplumda bir arada yaşamayı mümkün kılan ilişkilerin, o toplumun gereklerine uygun olarak uyumluluk temelleri üzerine kurulmasıdır. İnsanın olduğu her yerde, farklı çıkarlar ve ihtiyaçlarla karşılaşılacağı için uyumsuzluk veya düzensizlik ortaya çıkabilir. Düzen kurallar ile sağlanır. Toplumsal yaşamın sağlıklı bir şekilde yürütülebilmesi ve düzenin sağlanabilmesi için toplumsal ilişkilerin birtakım kurallara bağlanması gerekir. Hukuk kuralları; din, ahlak, görgü, örf ve adet kuralları gibi toplumsal yaşamı düzenleyen kurallardan birisidir, ama en etkili olanıdır. Toplumsal ilişkileri düzenleyen uyulması zorunlu kurallar topluluğuna hukuk denmektedir. Günlük kullanımda hukuk dendiği zaman, bazen geniş anlamda hukuk düzeninin kendisi, bazen, daha dar olarak uygulanan hukuk kuralları, bazen ise, olması gereken kurallar ifade edilmek istenir (Ertan, 2004: 371). 
Hukuk düzeni, insan için, insan toplumu için önem taşıyan bütün toplumsal sorunların çözümünde en önde gelen araçlardan biridir. Hukuk kurallarının amacı, toplum içinde düzenin sağlanmasıdır. Bu düzeni sağlayacak, kuralları koyacak bir otoritenin varlığı kaçınılmazdır. Hukuk kurallarının ön yüzü hak, arka yüzü sorumluluktur. Bu kuralların dışına çıkanlar çeşitli yaptırımlara uğrarlar. Yaptırım, hukuk kuralının yap dediği yapılmadığı, yapma dediği yapıldığı zaman karşılaşılan şeydir. Hukuk kurallarının oluşması ile devletin bireylerle ve bireylerin devletle olan ilişkisi belli kurallar çerçevesine oturtulmaktadır. Normlardan oluşan hukuk kuralları maddi yaptırımlıdır. $\mathrm{Bu}$ hukukun önemli kavramlarından biri olan ceza ile karşılık bulur. Kurallara uyulmaması durumunda, uymayanın cezalandırılması hukuk devleti olmanın bir gereğidir. Suç ve suçluluk, hukuksal normların ihlalidir. Suçlar, ağır veya hafif olabilir. Kişilere, mala, topluma, devlete ve uluslararasına karşı işlenebilir. Hukuk kurallarına uyulmadığında para, hapis, meslekten men cezası gibi yaptırımlarla karşılaşılır. Hukuk kuralları, toplumsal alanda değişen toplumsal ihtiyaçları karşılamak için ortaya çıkmıştır. Bu da, kimi kuralların hukuksal bir yapıya kavuşması için bir oluşum ve olgunlaşma sürecinin geçmesini gerektirmiştir. Hukuk denince, hemen onun kurallarla sabitlenen statik yanı akla gelir. Ama hukuk değişen koşullara uygun olarak kendini yenilemek ve dinamik olmak zorundadır. Yoksa hayatın akışını yakalayamaz (Aybay, 1997: 310).

Çevrenin hukuksal bir özellik kazanması, toplumsal alanda bir takım gelişmelerin sonucunda olmuştur. Bu gelişmelerden en önemlisi, çevre sorunlarının, 20. yüzyılın ikinci yarısından sonra tehlikeli boyutlara ulaşınca, büyük bir önem kazanması ve bütün toplumlar için, önde gelen, çok yönlü ve çok boyutlu sorunlardan biri haline gelmiş olmasıdır. 20. yüzyıla gelinceye kadar insanın yaşam çevresini ve sağlığını olumsuz biçimde etkileyen çevre sorunları ile karşılaşılmakla birlikte, bütün olarak canlı yaşamını ve hatta bu ilişkiler bütününü oluşturan ekolojik dengeyi tehdit eden ciddi çevre sorunları ortaya çıkmamıştı. Çevre sorunlarının kendini yoğun bir şekilde hissettirmesi üzerine, sorunun bütün insanlığı ve dünyanın geleceğini etkilediği net bir şekilde 
anlaşılmıştır. Küresel ekolojik (çevre ile ilgili) yıkımın öngörü olmaktan çıkıp, iklimin değiştiği, doğal hayatın yok olduğu, tüketim anlayışının hayatımızı kapladığı, genlerin dahi kontrol edilebildiği bir dönemde tüm dünyaya egemen olan yok etme kültürü toplumsal düzeni gittikçe daha çok tehdit etmektedir (Erdoğan, 2009:2). Öyle ki, çevreye ilişkin sorunlar, ülkelerin tek başına çözemeyecekleri kadar büyümüş, insanlığın yaşamını tehdit eder hale gelmiş; gelecek için bir güven sorunu oluşturmuş ve suç olarak nitelendirilmeye başlanmıştır. Çevre bilinci ve duyarlılığının yavaş bir süreç içinde de olsa gelişmesine koşut olarak, ekonominin ve gelişmenin kaynağı olarak görülen su, toprak ve hava gibi çevresel değerlerin korunması gerektiği düşüncesi, toplumsal yaşama egemen olmaya başlamıştır. Çevresel değerlere hukuksal güvenceler kazandırılması gereğinin duyulmaya başlanması, çevreyle ilgili birtakım önlemler alınması gerekliliğini de beraberinde getirmiştir.

Bu kadar çok boyutu olan bir konunun hukuk ile bağlantısının kurulması doğal bir olaydır. Çevre ile insan arasındaki ilişkileri düzenlemek, belli davranış kuralları getirmek, çevresel sorunları çözmek için, kullanılabilecek en etkili araçlardan biri kuşkusuz hukuk düzenidir. Çevre sorununu çözecek kurallar elbette hukuk kuralları biçiminde olacaktır. Devlet diğer sorunların çözümünde olduğu gibi çevre sorunlarının çözümü konusunda da birtakım yetkiler kullanacaksa bunu hukuk kuralları çerçevesinde yapmak zorundadır (Aybay, 1997: 311). Bu iş sözle olabilecek aşamayı geçmiştir. Çünkü kişi ve kurumlara yapılan uyarıların gücü bir yere kadar gitmekte, o kişi veya kurumlarda çevresel algı ve duyarlılık yoksa sorunlar çözümsüz kalmaktadır. İnsanın refah seviyesini yükseltmek kadar, çevreyi korumak ve iyileştirmek de modern sosyal devletin zorunlu bir görevidir. Toplumsal düzenin yeniden istikrarlı bir hale gelmesi için bu alanda hukuk kuralları ile bir düzenleme yapmanın zorunluluğu ortaya çıkmıştır. Bu nedenle, sorunlarının çözümü için temel koşul, çevreye ilişkin hukuk kuralları oluşturmaktır. Hukuk metinleri yazılı olan kurallardır, soyut, genel, objektif ve süreklidir ve yaptırım özelliği vardır. Sonuçta gelinen aşamada, bu sorunu çözmek için üretilen politikaların uygulama aracı olarak, bağımsız bir hukuk dalı oluşturacak ölçüde 
hukuk kuralları üretilmeye başlanmıştır. Bütün bunların toplamında, insanın çevresini oluşturan öğelerin hukukunu düzenleyen yeni bir hukuk dalı olarak çevre hukuku ortaya çıkmıştır.

Çevre hukuku, insanın doğal ve yapay çevresini oluşturan öğeleri koruyan, geliştiren ve onların hukuksal durumlarını düzenleyen bir hukuk dalıdır (Hamamcı, 1983:245). Çevre hukuku, çevresel değerlerin hukuksal güvenceler yaratılarak korunmasına yönelik çalışmalar bütünü olarak ifade edilebilir. Doğanın bir parçası olan insanın geleceği için, doğayı korumayan bir anlayış olamaz. Bu yüzden, çevre hukukunun temel felsefesi, doğayı ve canlı yaşamını (bitkileri, hayvanları ve insanları) korumadır. Bu koruma, kirletmeden koruma şeklinde hayata geçer. Çevreyi insana rağmen korumaya çalışır. Bu koruma; kirliliği ortaya çıkmadan önlemek, ortaya çıkmış kirliliği tedavi etmek ve çevreyi geliştirmek unsurlarına dayanır (Ertan, 2004: 373). Bu bilgiler ışığında, çevre hukukunu; çevrenin düzgün kullanılması, temiz tutulması, kirlenmekten korunması ve kirlenen çevrenin temizlenmesi amacıyla alınan önlemleri düzenleyen hukuk kurallarının tümüdür diye tanımlayabiliriz. Çevre hukuku, insan etkinliklerinin çevrenin korunması amacıyla sınırlandırılmasını hedefler. Ama, çevre hukuku çevre sorununun sadece dolaylı bir çözüm aracı değildir. Gerektiğinde, doğrudan çözüm kapsamlı bir "çevre politikası" ile gerçekleşir. Hukuk kuralları ancak böyle bir politika ile belirlenmiş esaslara ya da amaçlara göre işlev kazanır. Çevre hukuku ile ilgili açıklamalarda "çevre" en geniş anlamıyla ve dinamik yanıyla kullanılır. Çünkü, çevre hukuku, zamana ve mekâna uygun çözümler geliştirebilmek için; statik kalmamalı, toplumsal koşullara uyum sağlama yeteneğine ve esnekliğine sahip olmalıdır. Bugün bütün dünya ülkelerinde hukukun gelişime ve değişime açık yönünün en önemli göstergelerinden birisi çevre hukukudur. Çevre hukuku, 20. yüzyılda doğan ve gelişen bir hukuk dalıdır; oluşması oldukça yenidir. (Ürkmez, 2005). Özellikle yeni ve bağımsız olarak kabul edilen bir hukuk dalı olarak, ancak 20-30 yıllık bir geçmişi vardır. Çok genç olan ve hukuk içinde kesin yeri belli olmayan bu hukuk dalının hukuk sistemine ilişkin klasik ayrımdaki yerinin saptanması önemli bir sorundur. Korunması amaçlanan çıkar ve 
değerlere ve uygulamayı yürütecek örgütün özelliklerine göre, çevre hukukunun "kamu” ağırlıklı olduğu kuşkusuzdur. Ancak, özel hukuk alanındaki borçlar ve medeni hukuk gibi alanlardan da yararlanmaktadır, karma nitelikli sayılabilir. Çevre hukukunun; dinamik olma, disiplinlerarası olma, karma hukuk dalı olma, geniş kapsamlı ve sınırlayıcı olma nitelikleri vardır (Ertan, 2004: 374). Çevre hukukunun kaynaklarını, ulusal ve uluslararası kaynaklar olarak iki başlık altında ele almak mümkündür. Ulusal kaynaklar kapsamına; anayasal düzenlemeler, yasal düzenlemeler ve diğer düzenlemeler girmektedir. Uluslararası kaynaklar ise; anlaşmalar, sözleşmeler ve uluslararası teamül hukuku olarak sayılmaktadır.

Türk hukukunda çevre kirlenmesinden oluşan zararların tazminine ilişkin düzenlemeler, hukukun gelişimine göre üç evrede incelenebilir; ilk evrede, komşuluk hukukuna ilişkin hükümlerle yetinilmiştir. Komşuluk hakkı düzenlemesi çevre kirlenmesinin ulaştığı boyutlar nedeniyle yetersiz kalmıştır. Ikinci evrede, tehlikeli faaliyetler için yasalar çıkarılmıştır. Zararın karşılanması önemli bir sorun olarak ortaya çıkmıştır. Üçüncü evre ise, çevreye verilen zararların önlenmesi ve zararların tazmini için özel düzenlemelerin yapıldığı aşamadır (Ertürk, 1996:174). Dünya genelinde 1970'li yıllarda genelde çevre sorunları, özelde de çevre kirlenmesi sorunları hissedilmeye başlanmıştır. Ulusal ve uluslararası düzeylerde birçok çevresel etkinlik gerçekleştirilmiştir. 1970'li yılların sonlarına doğru, çevre sorununun hukuksal boyutları iyiden iyiye belirginleşmeye başlamıştır. Çevre sorunlarına çözüm arama çabalarında, gerek ulusal gerek uluslararası düzeylerde, başlangıçta, yönetim hukuku ve kısmen de özel hukuk normlarına ağırlıklı olarak başvurulmuş, ceza hukuku yaptırımlarının kullanılması pek konu edilmemiştir. Hukuki metinlerin hemen hepsinde, getirilen kuralların ihlali halinde uygulanması kabul edilen yaptırımlar da büyük ölçüde yönetsel ve hukukî yaptırımlar şeklinde olmuştur (Turgut, 2001: 613). Aynı sürecin izlendiği ülkemizde, çevreye ilginin bu yıllarda başladığı bilinmektedir. Çevreye ilişkin yasal düzenlemeler dolaylıdan doğrudan düzenlemeye doğru Dünya'daki gelişimi takip etmiştir. İlk dönemde, çevre ile doğrudan ilgili olmamakla birlikte, çevre koruma amacına hizmet eder biçimde 
kullanılagelen yasal düzenlemeler yapılmıştır: İl İdaresi Kanunu, Medeni Kanun, Ceza Kanunu, Borçlar Kanunu, Yeraltı Suları Kanunu, Su Ürünleri Kanunu, Kara Avcılığı Kanunu gibi çeşitli sorunlara çözüm bulmayı amaçlayan ve çevreye ilişkin bazı hükümleri içeren yasalardır (Ertürk, 1996: 187; Ürkmez, 2005). Özel hukuk açısından, Medeni Yasa, kişiler arasında çevre yüzünden çıkan anlaşmazlıklarla ilgili kurallar taşımaktadır. Medeni Yasanın 737. maddesi; bir kimsenin malını kullanırken koku, gürültü ve duman gibi zararlı maddeler çıkararak başkalarına zarar vermemesini, zarar verenlerin cezalandırılmasını öngörmektedir. Taşınmaz mülkiyetin taşkın kullanılmasının sorumluluğu kusura dayanmayan bir sorumluluktur. Medeni Yasa, kusura dayanmayan sorumluluğu kabul etmekle Çevre Yasasında öngörülmüş "kusursuz" ya da "objektif sorumluluk ilkesini" benimsemiş olmaktadır (Ertan, 2004:380). Çevreye ilişkin ilgi 1980'li yıllardan itibaren artmış ve bu ilgi yapılan anayasaya da yansımıştır. 1982 yılından sonra başlayan dönemde, doğrudan doğruya çevre korumasına ve geliştirilmesine yönelik yasal düzenlemelerin yapıldığı gözlenmektedir. Bu dönemde yürürlüğe giren; Çevre Kanunu, Çevre Bakanlığının Kuruluş ve Görevleri Hakkında Kanun Hükmünde Kararname çevre ile ilgili mevzuatı oluşturur (Ertürk, 1996: 187-188).

Çevrenin korunmasına ilişkin hukuki metinlerde, insanı temel alan "antroposentrik" ve doğayı temel alan "ekosentrik" yaklaşım olmak üzere iki farklı yaklaşım benimsenmektedir. 1982 Anayasası'nda antroposentrik yaklaşım benimsenmiştir. 1982 Anayasasında çevre konusu doğrudan ve dolaylı olarak birkaç maddede yer almıştır. Anayasamızın Sosyal ve Ekonomik Haklar ve Ödevlerle ilgili Sağlık Hizmetleri ve Çevrenin Korunması başlığını taşıyan 56. ve Tarih Kültür ve Tabiat Varlıklarının Korunması başlığını taşıyan 63. maddeleri çevrenin korunması ve çevre kirliliğinin önlenmesine ilişkindir. 3. bölümdeki çevre ile doğrudan ilişkili olan "çevre hakkı"na ilişkin düzenleme şöyledir: "Herkes sağlıklı ve dengeli bir çevrede yaşama hakkına sahiptir. Çevreyi geliştirmek, çevre sağığını korumak ve çevre kirlenmesini önlemek devletin ve vatandaşların ödevidir." Bu madde çevre hakkını anayasal bir hak haline 
getirmiş ve sağlıkla birlikte düşünmüştür. Çevreyle ilgili bu maddenin anayasada yer alması çevre duyarlılığının gelişmesinin bir ürünüdür. Madde, çevreyi korumak açısından devlete ve vatandaşlara hukuksal bir ödev ve sorumluluk yüklemiştir. Anayasal düzeydeki bu gelişme pozitif hukuka da yansıyarak, çevre hukukunun gelişmesine neden olmuştur (Ertürk, 1996: 188).

Anayasa başta olmak üzere, iç hukukta çevre korumaya ilişkin düzenlemelerin yapılması ve çevre korumaya ilişkin anlaşma ve sözleşmeler yoluyla çevrenin ulusal hukukun ilgi alanına sokulması, çevre hukukunun ülkemizde gelişimini doğrudan etkileyen gelişmeler olmuştur. Türkiye'de çevre politikalarını yönlendiren temel yasa, kuşkusuz Anayasanın 56. maddesine dayanılarak çıkarılan 2872 sayılı Çevre Yasası'dır. Anayasada yer alan ilke doğrultusunda, çevre korunmasına ilişkin oluşturulan yasa hukuk sistemimizdeki yerini almıştır. Çevre Yasası, Türkiye'nin çevre ile ilgili temel yasalarından biridir. 26.04.2006 tarih ve 5491 sayılı yasa ile pek çok maddesi değiştirilen ve 26 Nisan 2006 tarihinde yürürlüğe giren yeni 2872 sayılı Çevre Yasası'nın 3/a maddesine göre, çevrenin korunması bütün yurttaşların ortak ödevi kabul edilmiştir: "Başta idare, meslek odaları, birlikler ve sivil toplum kuruluşları olmak üzere herkes, çevrenin korunması ve kirliliğin önlenmesi ile görevli olup bu konuda alınacak tedbirlere ve belirlenen esaslara uymakla yükümlüdürler". Çevre Yasasının amacı; bütün vatandaşların ortak varlığı olan çevrenin korunması, iyileştirilmesi, kırsal ve kentsel alanda arazinin ve doğal kaynakların en uygun şekilde kullanılması ve korunması; su, toprak ve hava kirlenmesinin önlenmesi; ülkenin bitki ve hayvan varlığı ile doğal ve tarihsel zenginliklerinin korunarak, bugünkü ve gelecek kuşakların sağlık, uygarlık ve yaşam düzeyinin geliştirilmesi için yapılacak düzenlemeleri ve alınacak önlemleri, ekonomik ve sosyal kalkınma hedefleriyle uyumlu olarak hukuksal ve teknik esaslara göre düzenlemektir.

Çevreye ilişkin yasa ve düzenlemelerin bir takım kişi veya kuruluşlar tarafından ihlal edilmesi durumunda çevre suçu işlenmiş olmaktadır. Çevre suçu, çevresel değerlere 
zarar verilmesi ve ortadan kaldırılmasına yönelik işlenen suçlardır (Kaya ve Ertürk, 2008:88). Bu doğrultuda, 2872 sayılı Çevre Yasası'nın benimsediği en önemli ilkelerden birisi "kirleten öder" ilkesidir. Çevre Yasası kirleten öder ilkesini, Çevrenin Korunması, İyileştirilmesi ve Kirliliğinin Önlenmesine İlişkin Genel İlkeler başlığı altındaki 3/g maddesine göre; "Kirlenme ve bozulmanın önlenmesi, sınırlandırılması, giderilmesi ve çevrenin iyileştirilmesi için yapılan harcamalar kirleten veya bozulmaya neden olan tarafından karşılanır" diye ifade etmektedir. Çevre Yasası'nda kirletenin sorumluluğu konusunda çevre koruma düşüncesi ilke olmaktadır. Çevre Yasası́nın Kirletenin Sorumluluğu ile ilgili 28. maddesine göre; “çevreyi kirletenler ve çevreye zarar verenler sebep oldukları kirlenme ve bozulmadan doğan zararlardan dolayı kusur şartı aranmaksızın sorumludurlar." Böylece yasa kirletenlerin kusursuz sorumluluğunu öngörmektedir. Yasa ile öngörülen yasaklara uymayan kurumlara yaptırım uygulanacağı, hatta faaliyetlerinin durdurulabileceği hükme bağlanmıştır (md.15). Yasa çevre suçu için idari ve adli cezalara da yer vermiştir. Yasanın 20- 27. maddeleri para ve hapis cezası ile düzenlemeleri içermektedir. Çevre kirliliğine neden olduğu saptanan kurum, kuruluş ve işletmelere ağır yaptırımlar getirilmiştir (Yılmaz, 2009). Yasadaki yeni değişikliklerle kirliliğin bir yana bırakıldığı ve atıklara ağırlık verildiğini, sürdürülebilir çevre ve sürdürülebilir kalkınmanın öne çıkarıldığını, yeni tanımlar getirildiğini söylemek mümkündür. Ülkemizde ilk çevre yasası kabul edildiğinde, hava ve su kirliliği ağırlık taşımaktaydı, daha sonra atık kavramı ortaya çıkmış; ardından çevre hukukuna sosyal ve kültürel boyut eklenmiştir. Bunun nedeni çevre konusundaki sorunların giderek yoğunlaşmasıdır.

2872 sayılı Çevre Yasası'nda idari yaptırım öngörülen çevre suçları, 5237 sayılı Türk Ceza Kanunu'nun (TCK) yürürlüğe girmesi ile ayrı bir boyut kazanmıştır. Kamu hukuku açısından Ceza Yasasına çevreyi kirletenlerin bu eylemlerine karşı bir yaptırım olarak öngörülen ceza konmuştur. Bu süreç benzer bir şekilde bizim ülkemizde de işlemiş ve Türk Ceza Kanunu’nda Topluma Karşı Suçlar başlıklı üçüncü kısımda "çevre suçları" adlı bir bölüm oluşturulmuştur. Dünya üzerinde ilk kez Türkiye'de kabul edilen bir Ceza 
Yasasında yasanın amaçlarından birinin çevreyi korumak olduğu belirtilmektedir. Ceza Kanunun 181. maddesi çevrenin kasten kirletilmesi hakkında hapis cezasını, 182. maddesi çevrenin taksirle kirletilmesi hakkında adli para cezasını gerektirmektedir. Çevre suçlarına yönelik gücü artırılan çevre cezaları caydırıcı olabilir. Ayrıca, Türk Ceza Kanunu "kovuşturma ve soruşturma gereken bir fiilin ilgili makamlara bildirilmemesi, hatta bu hususta gecikme gösterilmesi halinde ilgili kamu personeli hakkında da işlem yapılacağını" hüküm altına almıştır. Bunun anlamı, çevre kirliliği ile ilgili her saptamada konunun TCK'nın ilgili hükümleri kapsamında değerlendirilmek üzere Cumhuriyet Savcılıklarına bildirileceği, Savcılıkların talebine dayanarak Sulh Ceza Mahkemeleri nezdinde kamu davası açılabileceğidir.

Çevre kirliliği ile ilgili olarak herkesin yürütme organlarına müracaat hakkı vardır. Bu hak 2872 sayılı Çevre Yasasının 30. maddesinde yaralan "çevreyi kirleten veya bozan bir faaliyetten zarar gören veya haberdar olan herkes ilgili mercilere başvurarak faaliyetle ilgili gerekli önlemlerin alınmasını veya faaliyetin durdurulmasını isteyebilir" hükmü ile yinelenmiştir. Çevre hukukunda daha çok sübjektif sorumluluk değil, objektif hukuk kuralları geçerlidir. Kusura dayanmayan sorumluluk, kusura dayalı sorumluluktan daha toplumsal bir düşünceye dayanmaktadır (Yılmaz, 2009). Yine de, TCK'nın bugünkü haliyle yeterli olduğu söylenemez. Zira yasada ağır çevre kirletme fiillerini suç sayan düzenleme yoktur. Çevrenin korunmasına yönelik hükümler yasada dağınık bir şekilde yer almış ve yerine göre kişiye karşı veya mala karşı işlenen suçlar için öngörülmüş olan koruma amacının "arkasında" tutulmuş ve çevresel değerlerin korunması ikincil (tali) amaç olmuştur (Mert, 2009).

Günümüzde önemli bir sorun olan çevre kirlenmesi konusunda kusura dayalı sorumluluk ilkesi yetersiz kalmaktadır. Sübjektif sorumlulukla kirlilikle tam olarak mücadele etmek zordur. Kirlilikle mücadele etmek ve o kirliliği bir an önce ortadan kaldırmak gerekir. Failin bulunması, yargılamanın uzaması, kirliliğin uzamasına neden olur. Çevre kirlenmesi çok teknik bir konu olmakta ve kirlenmenin varlığını ve 
kirlenmeden zarar görüldüğünün ispatı çok uzun zaman almaktadır. Ayrıca, bazı durumlarda kirlenmeden sorumlu olan kişinin ve sorumluluk derecesinin saptanması sorun olabilmektedir. Bu güçlük, özellikle birden fazla kirletici şahıs ve kurum bulunduğunda ortaya çıkmaktadır. Örneğin, sanayi kuruluşları bir bölgede topluca bulunduklarında sorumlu saptamak zor olmaktadır. Ayrıca, çevre kirlenmesi genellikle bir kişiyi değil, birden çok kişiyi etkilemektedir. Kirleten ve kirlenenin saptanmasında ve bunların etkilenme derecelerinin bulunmasında sorunlar olmaktadır. Kirletenlerin topluma verdikleri zarar çok fazla ise, kirleten öder kuralı işlemez hale gelebilmektedir (Keleş ve Hamamcı, 1993: 138). Bu nedenle "kirleten öder" ile çevre hukukunda daha çok objektif kurallar geçerli olmaktadır. Böylece, tazminat hukukunda zarar gören ön plana çıkarılarak, zarar vereni sorumlu kılmaktan çok zararın karşılanması amaçlanmaktadır (Ertürk, 1996: 175-177). Bu davalara yönetsel yargıda görevli idari mahkemeler ve Danıştay bakmaktadır. Henüz bir çevre mahkememiz yoktur. Mahkemenin açılmasına duyulan ihtiyaç arttığında kurulacaktır. Çünkü hukuksal düzenlemeler istek ve talepleri izlerler.

\section{4. ÇEVRE HUKUKUNUN ULUSLARARASI BOYUTLARI}

Çevre, sadece ulusal veya bölgesel alanda ortaya çıkan bir sorun olmayıp, küresel yapıda karmaşık bir sorundur. Dünyadaki çevre sorunlarının ülkesel temeldeki çözümlerinin yeterli olmadığı, diğer ülkelerle işbirliği yapılarak çözülebileceğinin anlaşılması üzerine, sorunun çözümü için, ülkeler arasında zorunlu bir yakınlaşma söz konusu olmuş; devletler arasında ortak kurallar ve standartlar oluşturma girişimleri başlamıştır. Uluslararası alanların yönetimi konusunda, daha önceki uygulamaların çevre sorunlarının çözümünde başarısız olması bu çabaları tetiklemiştir. Çevrenin uluslararası bir boyut kazanması ile bu sorunları hukuk ilkelerine uygun olarak çözme çabaları, uluslararası hukukun bir alt dalı olan uluslararası çevre hukukunun oluşumu için gerekli yolu açmıştır. 
Çevre hukukuna uluslararası bakış, ulusal bakıştan farklı olmamıştır. Yakın zamanlara kadar, dünyada küresel bir çevre koruma politikasından bahsetmek olanaksızdı. Oysa bugün çevreye ilişkin pek çok düzenleme yapılmıştır ve yapılmaktadır. Bu gelişmelerde en önemli aşama hiç kuşkusuz 1970 sonrası meydana gelen gelişmelerdir. Gelecek kaygısı ve dünyanın geleceğini korumak isteği, toplumların çevre sorunlarına daha ciddi olarak eğilmelerinde temel etmen olmuştur. Çevre sorunları değişik etkinlik ve düzenlenen konferanslarla toplumların gündemine yerleşmiştir. Dünyanın doğal kaynaklarının sahip olduğu sınırlı kapasitenin, artan nüfus ile genişleyen tüketim eğilimleri karşısındaki durumu Roma Kulübü tarafından 1972 yılında hazırlanan Büyümenin Sınırları (The Limits to Growth) isimli raporla tartışılmaya başlanmıştır. Rapor, dünyanın sahip olduğu sınırlı miktarda ekilebilir alan, enerji kaynağı, maden rezervi ve kirliliği kaldırma kapasitesi dolayısıyla; giderek artan nüfusun, ekonomik faaliyet hacminin ve çevre kirliliğinin sınırlanması gereğini vurgulamaktadır (Kula, 1994: 27). Herhangi bir yaptırımı olmasa da, Büyümenin Sınırları'nın başlıca olumlu etkisi; insan ihtiyaçlarının yeryüzündeki sınırlı doğal kaynak zenginliği ile karşılanması noktasında; doğal kaynakların tükenmesi, çevresel bozulma ve yaşam kalitesi ile ilgili konular üzerine dikkat çekmek olmuştur. Çevreye ilişkin düzenlemelerin uluslararası alanda gelişmesi çevre bilincinin gelişmesini izlemiştir. Bu dönemde çevre bilincinin kitleler arasında yayılması ile çevre örgütleri, siyasal iktidarlar üzerinde önemli bir baskı unsuru olarak ortaya çıkmıştır. Bu baskı çevrenin hukuksal bir zemin kazanması için de itici bir güç olmuştur (Aybay, 1997: 218).

Çevre hukukuna özgü kurallaşmanın bir hukuk dalı oluşturması yeni bir olgu olmakla birlikte, bu daha önce, çevre sorunu ile ilgili hiçbir kuralın mevcut olmadığı anlamına gelmez. Aslında insanlar, toplu olarak yaşamaya başladıkları zamandan beri, gereksinmelerini karşılayan doğal kaynakların kullanılmasında, özellikle topraktan ve su kaynaklarından yaralanmada belli bir düzen kurmaya çalışmışlardır. Eski zamanlarda da çevrenin hukuksal yollarla korunmasına ilişkin kurallara rastlanmaktadır. Roma hukukunda çevreye ilişkin konulmuş kurallar vardır. 19. yüzyıldan itibaren birçok 
Avrupa ülkesinde doğal kaynak kullanımı konusunda çeşitli hukuksal düzenlemelerin yapıldığı bilinmektedir (Aybay, 1997: 219). Çevre sorunlarının toplumsal yaşamdaki ağırlıkları ile orantılı bir biçimde hukuk düzenlemelerine konu olduğu gözlenmektedir. Önceleri çevre-insan ilişkileri komşuluk ilişkileri içerisinde algılanarak, kişinin mülkiyet hakkını kullanırken, başkalarına ve çevreye zarar vermekten kaçınması gerektiği düşüncesi ile birtakım yasal önlemlerin alınması yoluna gidilmiştir. Ne var ki, hemen her toplumda varlığına rastlanan bu tür düzenlemeler, olaya, çevre hukuku adı verilen hukuk dalının geniş bakış açısından bakılarak getirilmiş değildir. Toplum sağlığı, toprağın, yeşilin korunması, adil bölüşüm sağlanması, komşuluk ilişkilerinin düzenlenmesi gibi çeşitli amaçlarla yapılan bu tür düzenlemelerde çevre sorunu doğrudan çözümü hedeflenen asıl sorun değildir. Ulus ve uluslararası ayrımı yapılmadığından, dar bir bakış açısıyla olaya bakıldığı görülmektedir. Bu düzenlemeler çevreye ve çevre sorununa sadece dolaylı olarak düzeltici etkiler yapmaktadır. Oluşturulmaya çalışılan yasal düzenlemeler, insanın yaşadığı çevresine vermesi olası zararları önlemek amacındadır. Bakış açısı çevre koruma temelli değildir. Zaten bu önlemler, çevreye ilişkin sorunların çok büyük boyutlara ulaşması ile yetersiz kalmış; yeni yasal önlemlerin alınması gerekmiştir. Çevre sorunlarının karmaşık ve çözümü zor bir sorun haline gelmesi, devletlerin bu konuda izledikleri politikalardan kaynaklanmaktadır. Endüstriyel modern toplumda insanın yaşam koşulları ve refah seviyesi sürekli yükselmektedir. Modern refah toplumların sürekliliği devletin yapmış olduğu bir takım altyapı hizmetlerine sıkı sıkıya bağlıdır. Eğer devlet bu hizmetleri yerine getirmez ise, modern toplumun varlığından sözetmek mümkün olmaz. Ancak ekonomik gelişme, bir yandan insana refahının artması gibi bir takım avantajlar kazandırırken, diğer yandan da, çevre için kirlilik gibi dezavantajlar getirmektedir. Refahın artmasının karşısında çevreye zarar verme yer almaktadır (Kılıç, 2001:133). Çevre, toplumların gündemine girdiğinden bu yana, toplumsal ve ekonomik alanda sürekli "ya ekonomi, ya çevre" gibi bir ikilem içinde görülmektedir. Ekonomik politikalar nedeni ile dünya ekonomisinin küreselleşmesi, devletin yönetim alanındaki yetkisinin 
daralması çevre-ekonomi ikilemini artırmıştır. Tahmin edileceği gibi, önce çevre değil, ekonomi tercih edilmiştir. Ancak, endüstriyel devletlerin bir çıkmaz gibi görünen bu durum karşısında, kimi zaman çevre değerlerini, kimi zaman da ekonomiyi öne çıkaran politikalar izledikleri görülmektedir. Batı ülkeleri bu ikilemden çıkmaya çalışmış; çevre konusunun devlet politikalarının bir parçası olması ve çevreye ilişkin düzenlemelerin ağırlık kazanması sürekli bir artış göstermiştir. Bütün ülkelerde çevreye ilişkin yasal düzenlemelerin değişen toplumsal koşullara ve karşılaşılan sorunların niteliğine paralel bir biçimde değişim gösterdiği görülmektedir. Bu yasal değişimlerin dolaylı düzenlemelerden dolaysız düzenlemelere doğru bir gelişim gösterdiği söylenebilir (Ertürk, 1993: 187).

Gelişmiş ülkelerde daha sonra ulusal metinlerde çevrenin korunmasına ilişkin olarak ilk aşamada bazı yönetsel yaptırımlar öngörülmüş; ancak zamanla bu yönetsel yaptırımların yeterli olmadığı anlaşılarak, çevreye dair hükümlere ve cezai yaptırımlara yer verilmeye başlanmıştır. Çevre hukukunun gelişmesinde uluslararası hukuk çok önemli bir yere sahiptir. Çeşitli hukuksal belgelerde ortaya çıkan çevre korumaya yönelik düzenlemeler gün geçtikçe artmış ve başta Avrupa ülkeleri olmak üzere, birçok ülkede çevreyle ilgili iç hukuk düzenlemeleri bir hukuksal metinde birleştirilmeye çalışılmıştır. Toplumsal alanda ortaya çıkan bu gelişmeler sadece gelişmiş ülkelerle sınırlı kalmamış; giderek gelişmekte olan ülkelere de yayılarak, bütün dünya üzerinde etkisini göstermiştir. Böylece, çevre konusunda bir takım yasalar birbirini takip etmeye; çevreye ilişkin hükümler mevzuatta yer almaya başlamıştır. Birçok ülke anayasasında çevrenin korunmasına ve geliştirilmesine yönelik devlete-bireylere ödev ve sorumluluklar yükleyen düzenlemeler görülmeye başlanmıştır (Özdek, 1993: 66). Çevrenin korunması, iyileştirilmesi ve çevre kirliliğinin giderimine yönelik mevzuatta çevre ile ilgili bölümler oluşturulmuş, yasa, yönetmelik gibi düzenlemeler yapılmıştır (Kılıç, 2001:134). Uluslararası alanda çıkan sorunlar nedeni ile çevre devletlerarası ilişkiler açısından her geçen gün daha fazla önem kazanmaya başlamıştır. Çevre sorunlarının sınır tanımaması, kaybedilen çevresel değerlerin bütün insanlığın ortak 
mirası olması gibi nedenler, çevre sorunlarının küresel düzeyde ele alınmasını zorunlu kılmaktadır (Özdek, 1993: 66).

Uluslararası hukuk kurallarına göre çevre hukukunun düzenlenmesi demek, çevre sorunlarına ulusal düzenlemelerden farklı çözümler getirmek demektir. Ülkeler arasındaki çevre sorunlarının çözümünde; "antlaşmalar, uluslararası teamül, hukukun genel ilkeleri" denilen üç temel ilkeden yararlanılmaktadır. Bu temel ilkeler uluslararası örgütleri ve devletleri ön plana çıkarmaktadır (Pazarcı, 1983: 203). Uluslararası düzeyde çevreye ilişkin en önemli gelişme, konunun Birleşmiş Milletler (BM) tarafından ele alınmasıdır (Budak, 2004:387). Dünyada kapsamlı çevre koruma çalışmalarını başlatan uluslararası alanda faaliyette bulunan örgütlerin başında Birleşmiş Milletler gelmektedir. BM, çevrenin uluslararası düzeyde örgütlenmesinde en önemli kuruluştur. Çevre konusunda sürekli çalışmalar yapan bir örgüt olarak dikkat çekmektedir. Çevrenin korunması, iyileştirilmesi ve çevre kirliliği ile ilgili olarak Birleşmiş Milletler 1971 yılından beri çalışmalar yapmaktadır. BM, "tek bir dünyamız olduğu” gerçeğinden yola çıkarak, uluslararası topluluğun tüm üyelerini, aralarındaki çatışma ne olursa olsun çevre konusunda ortak davranmaya yöneltmek istemiştir (Hamamcı, 1997: 401). Bunu sağlamak için, uluslararası çapta konferansların toplanmasını sağlamıştır. Bu konferanslar devletlerarası yardımlaşma ve işbirliğinin temelini oluşturması açısından önemlidir. Bir önemli katkısı da, çevre sorunlarının ancak uluslararası bir işbirliği ile çözülebileceğini bütün dünyaya kabul ettirmiş olmasıdır. Çevrenin korunmasına ilişkin önlemler, başlangıçta, uluslararası konferanslarda bir takım ilkelerin kabulüyle oluşturulmaya çalışılmıştır. Uluslararası düzeydeki ilk çevre konferansı, Birleşmiş Milletler tarafından 5-16 Haziran 1972 tarihlerinde -aralarında Türkiye'nin de bulunduğu- 113 ülkenin katılımıyla Stockholm'de düzenlenmiştir. Birleşmiş Milletler Çevre ve Insan Konferansı adını taşıyan bu Konferansın çevre açısından önemi, çevre sorunlarının ilk kez uluslararası bir konferansa konu olması ve çevre hakkının uluslararası alanda dile getirildiği ilk toplantı olmasıdır. Çevre hukukunun gerek ulusal, gerekse uluslararası düzeyde gelişmesinde en önemli gelişme Stockholm Konferansı 
olmuştur. Uluslararası bilinç ve duyarlılığın ilk örneği olarak anımsanabilir. Alınan kararlar, çevre korumasına yönelik küresel bilincin oluşmasına ve "çevre hakkı"nın, insan haklarını oluşturan bir öğe olarak ifade edilmesine hizmet etmesi açısından önem taşır. Eğer çevrenin hukuksallaşması açısından bir başlangıç noktası alınacaksa, en uygun tarih Stockholm Konferansı'dır. Bu konferanstan önce uluslararası çevre hukuku, uluslararası hukuktan bağımsız bir dal değildi. Stockholm ile birlikte uluslararası çevre hukukunun ortaya çıkması için gerekli olan süreç başlamıştır (Özdek, 1993: 73).

Çevre ile ilgili çalışmalar yapan BM örgütünün uzmanlık birimlerinden Eğitim, Bilim ve Kültür Örgütü kısa adı ile UNESCO, insanlar arasında dayanışma duygusunu pekiştirmek için ortak değerlerin dayanışma yoluyla geliştirilebileceği bir ortam yaratmak istemiştir. Bu ortamı sağlamak için, yeni insan hakları grubu oluşturulmuştur. Temel haklar, ekonomik ve sosyal haklardan ayrı olarak yeni oluşturulan hakları üçüncü kuşak haklar olarak dünyaya duyurmuş; çevrenin üçüncü kuşak insan hakları kavramı arasında sayılması için çalışmıştır. Çevre hakkı, anayasal bir hak olarak ortaya çıkan, hukuk düzenini etkileyen gelişme, barış ve insanlığın ortak mirasından yararlanma hakkı ile birlikte üçüncü kuşak hakkı veya dayanışma hakları denilen yeni kuşak insan hakları arasında yerini almıştır (Hamamcı, 1983: 246). Çevre hakkı; bireye özgürlük, eşitlik ve refah içerisinde yaşayabileceği bir çevrenin gerçekleştirilmesini devletten istemek hakkını vermektedir. Çevre hakkı kavramından hareketle hukuk metinlerinde çevreye ilişkin düzenlemeler yer almaya başlamıştır. Son yıllarda yasalara ya da anayasalara giren ve çevre korumanın en etkin hukuksal aracı olan çevre hakkı, çevre hukukunun hem ulusal düzeyde hem de uluslararası düzeyde yetersizliklerin ve boşlukların meydana getirdiği açıkları gidermek amacı ile oluşturulmuştur (Özdek, 1993: 71). Çevre hakkının giderek daha fazla etkinlik kazanması ve yaygınlaşmasında, uluslararası alanda meydana gelen gelişmelerin yönlendirici etkisi bulunmaktadır. Çevre hakkının tanınmasında en önemli gelişme, bu hakkın devletin dışında bir organ tarafından denetlenip denetlenmeyeceği ile ilgilidir. Çevre hakkının ihlali durumunda, soruna ülke içinde bir çözüm yolu bulunamadığı durumda, sorunun ulus üstü makamlara gitmesi 
çevre hakkının korunması açısından önemlidir. Çünkü, çevre hakkının uluslararası ya da ulus üstü bir organ tarafından güvence altına alınması, devletin bu alanda hareket alanının kısıtlanması anlamına gelecektir. Bölgesel ölçekte kurulan insan haklarını koruma mekanizmaları genişletilerek çevre hakkını da kapsayacak şekilde düzenlenmiştir (Kaboğlu, 1996: 134). Illk bölgesel insan hakları sözleşmesi Avrupa Konseyi tarafından 1953 tarihinde yürürlüğe konulan Avrupa Insan Hakları Sözleşmesi'dir. 1978'de Amerika Devletleri Örgütü Amerikan Sözleşmesi yapılmıştır. Avrupa ve Amerika örgütlenmelerinin ardından üçüncü bölgesel örgüt olarak 1963 tarihinde Afrika Birliği Örgütü (ABÖ) yürürlüğe girmiştir. 1986'de yapılan Afrika İnsan ve Halkların Hakları Sözleşmesi'nin diğerlerinden farkı birinci ve ikinci kuşak hakların yanı sıra üçüncü kuşak hakları da düzenlemesidir (www.tmmob.org.tr, 2012).

Birleşmiş Milletler'in desteğiyle uluslararası düzeyde yapılan konferanslar, sözleşmeler çevrenin hukuksal bir zemine oturması için en önemli öğelerdir. Stockholm Konferansı ile başlayan süreç devam etmiştir. G.H. Brundtland'in başkanlığında oluşturulan BM Çevre ve Kalkınma Komisyonu'nun, 1987'de BM Genel Kurulu'na sunduğu, Brundtland Raporu olarak da anılan Ortak Geleceğimiz (Our Common Future) isimli rapor; "Sürdürülebilir Kalkınma" kavramını, küresel gündeme taşıyan ilk çalışmadır (Brundtland, 1987). Bu tarihe gelinceye dek, ekonomi ile çevreyi birbirine rakip iki olgu olarak değerlendiren hâkim "sürekli kalkınma” yaklaşımına alternatif olarak şekillenen sürdürülebilir kalkınma kavramı; ilk kez dile getirildiği Brundtland Raporu’nda "gelecek nesillerin ihtiyaçlarını karşılama yetenek ve olanaklarını kısıtlamaksızın, bugünkü ihtiyaçların karşılanması" olarak tanımlanmaktadır. Brundtland Raporu yayınlanıncaya dek küresel bakış, "kalkınmanın çevre üzerindeki olumsuz etkileri" konusuna odaklanmıştı; rapor ile birlikte "çevresel bozulmanın, ekonomik kalkınma üzerindeki olumsuz etkilerine" çevrilmiştir (Yıkılmaz, 2003:114). Stockholm Konferansından on yıl sonra 1992 yılında Rio de Janerio'da düzenlenen Birleşmiş Milletler Çevre ve Kalkınma Konferansı, 179 ülkenin devlet başkanları ve yetkililerini biraraya getirerek yapılan en büyük toplantı olma özelliğini taşımaktadır. 1982'den bu yana geçen on yıl içinde 
Stockholm Deklarasyonu hazırlanmasında öngörülmeyen asit yağmurları, ozon tabakasının incelmesi, Chernobil ve radyasyon tehlikesi, ormansızlaşma gibi bir dizi küresel çevre sorununun ortaya çıkması şimdiye kadar alınan tedbirlerin gözden geçirilmesi zorunluluğunu ortaya çıkardı. Rio De Janerio'daki BM Çevre ve Kalkınma Konferansı, ekonomi-çevre ilişkisine yönelik çift yönlü vurgunun; ekonomi lehine yapıldığına dikkat çekmektedir: “Ekonomik kalkınma çevreye rağmen gerçekleşemez ve kalkınmanın ihmal edilmesi durumunda, çevresel koruma sağlanamaz". Rio Bildirgesi, destek olacak bilgilenme hakkı, katılma hakkı ve başvuru hakkı gibi ikincil haklardan bahsetmektedir. Bunlar; yönetimin kararlarının oluşumuna, denetlenmesine, izlenmesine de katılmak ve gerekirse, usulsüzlükte başvuru hakkının kullanılması demektir. Rio Konferansının yararı; Gündem 21 ile Iklim Değişikliği Sözleşmesi ve Biyolojik Çeşitlilik Sözleşmesi gibi iki uluslararası sözleşmenin imzaya açılmasını, ormanların korunmasına yönelik ilkelerin saptanmasını sağlamış olmasıdır. Gündem 21; hükümetlerin, resmi ve sivil tüm örgütlerin, 21. yüzyılda yapmaları gerekenleri anlatan hukuken bağlayıcı olmayan bir anlaşmadır (Şahin, 2004:415). 1992 yılında Rio de Janerio Konferansı'nda imzaya açılan BM iklim Değişikliği Çerçeve Sözleşmesi, "ortak fakat farklılaştırılmış sorumluluk" çerçevesinde, ulusal ve bölgesel farklılıkları dikkate alarak, sera gazı salınımlarının azaltılması amacıyla taraflara ortak yükümlülükler getirmektedir (Ulueren, 2001: 39). BM İklim Değişikliği Çerçeve Sözleşmesi, atmosferdeki sera gazı birikimlerini durdurmayı nihai amaç olarak belirleyen bir küresel çevre düzenlemesidir. İklim Değişikliği Çerçeve Sözleşmesi doğrultusunda, 1997 yılında Japonya'nın Kyoto kentinde toplanılmış ve uygulanacak yükümlülükler ile mekanizmaların belirlendiği bir protokol üzerinde uzlaşılmıştır. Bu çerçevede oluşturulan Kyoto Protokolü, ülkelerin karbon emisyonu azaltma hedeflerine ilişkin taahhütlerini ve bu hedeflere ulaşmak için kullanabilecekleri esneklik mekanizmalarını içermektedir (Yıkılmaz, 2003: 303). Türkiye'nin de taraf olduğu Protokol, küresel çevresel politikalara uyum sürecini şekillendiren bağlayıcı bir düzenleme olarak, söz konusu politikaların gerçekleştirileceği genel bir çerçeve niteliğindedir (Güçlü, 2007). 
Çevre hukuku, ulusal düzeydeki yasalaştırma etkinliklerinin yanı sıra, uluslararası düzeydeki düzenlemeler ve örgütlenmeler ile de etkinlik oluşturmaktadır. Çevreye ilişkin uluslararası düzenlemeler, tavsiye niteliği ile bağlamış, bağlayıcı olmayandan bağlayıcı olana doğru bir gelişim süreci izlemiştir. Bu düzenlemeler şöyle gruplandırılabilir: Bağlayıcı olmayan-tavsiye niteliğinde-hükümetler arası deklarasyonlar, imzalayan devletleri bağlayıcı değildir, ama bağlayıcı ulusal ve uluslararası düzenlemelere çerçeve oluşturmaktadır. Örnek: 1992 Rio Deklarasyonu. Uluslararası kuruluşların küresel veya bölgesel ölçekte yasal düzenlemeleri; tüzükler, yönergeler, kararlar, tavsiye kararları, tavsiyeler, deklarasyonlar, uygulama kararları biçiminde olabilir ve duruma göre bağlayıcı olabilir veya olmayabilir. Bağlayıcı kararlara örnek olarak; BM Nesli Tehlikede Olan Hayvan ve Bitki Türlerinin Uluslararası Ticaretine ilişkin Sözleşmeye taraf olan ülkelerin, fildişinin ve balinaların ticaretini yasaklayan kararları gösterilebilir. Bağlayıcı antlaşmalar: hükümetler tarafından küresel veya bölgesel nitelikte kabul edilip imzalanan anlaşmalar ve hukuki düzenlemelerdir. Örnek: 1989 tarihli Basel Sözleşmesi, bu sözleşmeyi imzalayan devletleri bağlayıcı bir uluslararası hukuk belgesidir. Küresel bir boyut kazanan çevre sorunlarının önlenmesi, doğal kaynakların koruma ve kullanım esaslarının belirlenmesine yönelik uluslararası antlaşmalar, çevreyle ilgili yargı kararları ve bu yargı kararlarının sonucu oluşan içtihatlar, çevre hukuku ile ilgili önemli gelişmelerdir. Çevre hukuku olarak adlandırılan hukuk dalının temeli, bu kuralların toplamından oluşur. Çevre değerlerine hukuk güvencesi kazandıran örneklerin yaygınlaşmasıyla birlikte çevre hukukunun hareket alanı ve önemi gittikçe artmaktadır. Hemen her ülkede bu konu ile ilgilenen hukukçular, çevre hukukunun oluşmasında ve uygulanmasında görev yapmaya ve çalışmaya başlamışlardır (Kılıç, 2001:133-134).

Uluslararası örgütlenme ile ulus üstü örgütlenme arasındaki temel fark egemenlik konusudur. Uluslararası örgütlerde devletin egemenlik hakları saklı kalırken; ulus üstü örgütlerde üye devletler, belli alanlardaki egemenlik haklarını ulus üstü örgütlere devretmektedirler. Ulus üstü örgütlenmenin tipik örneği Avrupa Birliği'dir (AB). Birlik 
diğer uluslararası örgütlerin sahip olduğu statünün daha üstünde bir yetkiye sahiptir. $A B^{\prime}$ nin çevreye ilişkin almış olduğu kararlar bütün üyeler açısından bağlayıcıdır. Bu nedenle $A B$, devletlerin egemenliklerine belli ölçüde sınırlamalar getirmektedir. $A B^{\prime}$ nin amacı, bir takım ortak kuralları bütün üye devletlere uygulamaktır. Birliği'nin kurucu antlaşmasının 3.maddesine göre, ticaret, tarım gibi bir dizi ortak politikaların oluşturulması öngörülmektedir (Pazarcı, 1991: 62). Bu ortak kuralların oluşturulması için üye devlet, topluluk mevzuatına uygun olarak, uygulama ve yürütme yetkisini devretmektedir. AB'ye üye ülkeler, hem Birliğin mevzuatını kabul etmek, hem de Birliğin mevzuatına aykırı yasa çıkarmamak zorundadırlar. AB'ye katılan devletler, ilke olarak Birliğin organları tarafından daha önce yapılan hukuki işlemlere, katılma anından itibaren bağlıdır. Katılan ülke sınırlarında Birliğin yönetmelik adı verilen hukuki işlemleri, katılan ülkenin iradesine bağlı olmaksızın doğrudan uygulanır. İşlemlerin yürürlüğe girebilmesi için, ilgili devletin onayına gerek yoktur (Pazarcı, 1991: 62). Bu nedenle üyelerin yasama yetkisine belli ölçülerde sınırlama getirilmiştir. Avrupa Birliği tarafından kararlaştırılan tüzükler, direktifler ve kararlar üye ülkeleri bağlayıcı niteliktedir. Avrupa Birliği, 1970'lerden sonra çevreye giderek daha fazla önem vermiş ve bunun sonucunda 1972 yılında çevre konusu ele alınmıştır. Çevre ile ilgili bir eylem planı hazırlanması çağrısında bulunulmuştur. Bu gelişmeler sonucunda, Birinci ve İkinci Beş Yılık Çevre Eylem Programları hazırlanmış ve bu programlar Birliğin çevre politikalarında temel oluşturmuştur. Diğer bir önemli gelişme ise, daha önce çevre ile ilgili dolaylı hükümler içeren Topluluk Mevzuatının, 1986 yılında Avrupa Tek Senedi'nin imzalanması ile çevre konusunu doğrudan düzenleyen bir niteliğe bürünmüş olmasıdır. Kurucu antlaşmanın 25. maddesi ile "çevre" adı altında bir başlık eklenmesi öngörülmüştür (Hamamcı, 1997: 401). AET Kurucu Antlaşmasına eklenen çevre başlığı ile çevre değerlerinin korunması Topluluğun ortak amaçları arasına girmiştir (Özdek, 1993: 77). Diğer yandan, 1987 'de yürürlüğe giren ve Roma Antlaşması'nda değişiklik yapan Maastrich Antlaşması ile ilk kez çevreye ilişkin bir madde Birliğin temel amaçları arasında yer almıştır. Birliğin kurallarına göre, çevre dış ilişkilerde olduğu gibi, ortak 
yetki alanına giren konulardan biridir. (Yaşamış, 1995: 176). Henüz aday ülkeler de, Birliğin çevre alanında benimsediği standartları ve politikaları uygulamak ve ulusal mevzuata eklemek durumundadır (Özdek, 1993: 77).

Uluslararası çevre hukukunun gelişmesine katkı sağlayan en önemli gelişme, hassas durumda ya da tehdit altında bulunan yerlerin korunması için oluşturulan "uluslararası sözleşmeler"dir. Bu sözleşmeler sınır aşan kirlenmeler nedeni ile hava, deniz, toprak gibi değerleri korumayı, kirlenmeyi denetim altına almayı amaçlamaktadır. Çevre alanında uluslararası nitelikte pek çok sözleşme hayata geçirilmiştir. Örneğin, Endüstriyel Kazaların Sınır Ötesi Etkileri Sözleşmesi, Birleşmiş Milletler Deniz Hukuku Sözleşmesi, Sınır Ötesi Su Yollarının ve Uluslararası Göllerin Korunması ve Kullanımı Sözleşmesi bunlardan bazılarıdır. Bu sözleşmelerde bölgesel nitelikteki girişimler ağırlık kazanmıştır. Örneğin, Basra Körfezi için Kuveyt Sözleşmesi, Aden ve Kızıl Deniz için Cidde Sözleşmesi bu ölçekte yapılmış olan sözleşmelerdir. Bu sözleşmelerin temel amacı, sözleşmeye taraf olan devlete/devletlere denizlerde kirliliği azaltmak ve önlemek için gerekli önlemleri alma yükümlülüğünü getirmektedir. 1973 yılında Birleşmiş Milletler çatısı altında oluşturulan BM Çevre Programı kısa adı UNEP, Stockholm Çevre Konferansı'ndan sonra hayata geçirilmiştir. UNEP ulusal, bölgesel ve küresel bölümler içermektedir. Ancak örgütün çevreye ilişkin almış olduğu kararları, devletlere uygulatabilecek herhangi bir yaptırım yetkisi bulunmamaktadır, eylem planları şeklindedir. UNEP çatısı altında çeşitli bölgelerde yürütülen çalışmalardan bazıları şu şekildedir: Akdeniz Eylem Planı, Doğu Asya Bölgesi Kıyı Deniz Alanlarının Korunması İçin Eylem Planı vb. (Keleş ve Hamamcı, 1993: 163). Beş Yıllık Kalkınma Planlarında çizilen çerçeve içinde Türkiye, çevreye ilişkin uluslararası yükümlülüklerinin gereğini yerine getirmeye çalışmaktadır. Yaklaşık 200 kadar uluslararası sözleşmeye taraf olduğu gibi çok sayıda da bildiriyi imzalamış durumdadır. Türkiye'nin çevre konusunda özellikle Bildirge ve Şart niteliğindeki uluslararası belgeleri iç hukuk bakımından bağlayıcılıkları bulunmadığı için kabul etmede daha az duraksadığı yorumu yapılmaktadır (Algan ve Dündar, 2003:109). Oysa, Anayasa'nın 90. maddesi gereğince 
yasa ile onaylanmış olan uluslararası antlaşmaların yasa değerinde olması ve bunlara karşı anayasaya aykırılık iddiasının öne sürülememesi onları iç hukukta bağlayıcı duruma getireceği için, onaylama her zaman tercih edilmemektedir (Keleş, 2006:8). Uluslararası nitelikte olan ve Türkiye'nin de imzaladığı bazı sözleşmeler şunlardır: Denizlerin Gemiler Tarafından Kirletilmesinin Önlenmesine Ait Uluslararası Sözleşme (MARPOL-73/78), Akdeniz'in Kirlenmeye Karşı Korunmasına Ait Sözleşme, Karadeniz'in Kirlenmeye Karşı Korunması Sözleşmesi, Sulak Alanların Korunmasına İlişkin Sözleşme (RAMSAR), Birleşmiş Milletler Biyolojik Çeşitlilik Sözleşmesi, Dünya Kültürel ve Doğal Mirasının Korunmasına Dair Sözleşme (Dünya Mirası Sözleşmesi), Uzun Menzilli Sınır Ötesi Hava Kirlenmesi ile İlgili Sözleşme, Ozon Tabakasının Korunmasına Dair Sözleşme (Viyana Sözleşmesi), Tehlikeli Atıkların Sınır Ötesi Taşınımının ve Bertarafının Kontrolüne İlişkin Sözleşme (Basel Sözleşmesi), Nesli Tehlike Altında Olan Yabani Hayvan ve Bitki Türlerinin Uluslararası Ticareti Sözleşmesi (CITES Sözleşmesi), Nükleer Kaza Halinde Erken Bildirim Sözleşmesi (www.cevre.gov.tr, 2010).

Küresel çevre yönetiminin en önemli dayanağını "çok taraflı çevre anlaşmaları" oluşturmaktadır (UNEP, 2006:295). Örneğin, Gıda ve Tarım İçin Bitki Genetik Kaynakları Uluslararası Antlaşması, Antarktika Antlaşması (www.cevre.gov.tr, 2010). Çok tarafı çevre anlaşmaları, çevreyi korumayı, doğal kaynaklar üzerindeki insan etkisini yönetmeyi ve zararlarını engellemeyi amaçlayan yasal açıdan bağlayıcı nitelikteki hükümetler arası belgelerdir (Kaya ve Ertürk, 2008:85). Sözleşmelerde bulunan kurallarla, çevresel güvenliği tehdit edecek etkinliklerin denetlenmesi ve önlenmesi amaçlanmaktadır (Keleş ve Ertan, 2002: 241-242). Uluslararası sözleşmelere konu olan düzenlemeler, çevrenin esnek özelliği gereği çok boyutludur. Bir anlamda yeryüzünde nerede bir kirlenme ortaya çıkmışsa, onunla ilgili uluslararası sözleşme oluşturulmuş ya oluşturulmaya çalışılmıştır. Uluslararası antlaşmalar bile, çevre koruma açısından değerlendirildiğinde çok fazla engelleyici bir özellik göstermemektedir. Bunun bir gereği olarak, küresel sorunlar uluslararası alanda devletlerarası sözleşmelere konu olmaktadır. Bu düzenlemeler uluslararası çevre hukukunun en önemli belgeleridir 
(Özdek, 1993: 66). Diğer yandan, çevrenin esnekliği, en esnek davranılan konulardan biri olmasına neden olmuştur. Devletlerin sözleşmeye taraf olması, kendi iradeleri ile mümkün olduğu için, sözleşmenin etkinliği daha başlangıçta azalmaktadır. Devletler, hukuk kurallarının oluşturulmasında, uygulanmasında ve denetlenmesinde önemli rol oynamakta ve ülke sınırları içinde kurallar koyan tek organ olması nedeni ile amaç ve yetki açısından uluslararası örgütlere göre çok daha geniş bir yetkiye sahip bulunmaktadır (Pazarcı, 1983: 203-204). Diğer bir sorun, sözleşmenin imzalanmasından sonra, sözleşmenin uygulanması ve denetlenmesi sorununun da tam olarak çözülebilmiş olmamasıdır. Çevre konusunda uluslararası nitelikteki sözleşmelerin özelliği, devletler için geniş hareket olanakları getirmesidir. Eğer devletler isterlerse, belli bir süre sonra antlaşmadan çekilebilirler. Bu durumu iki açıdan değerlendirmek olasıdır: Birincisi, taraf olan devlete böyle bir olanağın verilmesi, çevrenin korunması açısından çeşitli sakıncalar doğurabilir. Bu yapılan sözleşmelerin zayıf noktasını oluşturmaktadır. Íkincisi, sözleşmelerin daha fazla devlet tarafından imzalanmasını teşvik edebilir (Kaya ve Ertürk, 2008:87). Gerçi uluslararası sözleşmelerde, sözleşmeye ilişkin herhangi bir sorun çıkması durumunda, sorunun nasıl bir yöntemle çözüleceği belirtilmiştir. Kimi sözleşmeler, sorunlu konuları aralarında görüşme yolu ile çözüm önerirken; kimi sözleşmeler, sorunun çözümü için yaptırımı olan hakem heyetleri ya da komisyonlar kurulmasını öngörmektedir. Örneğin, Nesli Tehlikede Olan Yaban Hayvanları ve Bitkilerine İlişkinin Sözleşmenin 18.maddesine göre, anlaşmazlık durumunda anlaşmazlığın görüşmeler yolu ile çözülemediği durumlarda sorunun Lahey Daimi Tahkim Mahkemesi'ne götürülebileceği belirtilmektedir (Çevre Mevzuatı, 1995: 20).

Bu nedenle, uluslararası çevre hukuku açısından en önemli etken devlettir. Uluslararası toplumun yalnızca devletlerden oluştuğu düşüncesine dayanan geleneksel görüş, uluslararası hukuku, devletler arasında ilişkileri düzenleyen kurallar bütünü olarak tanımlamaktadır. Buna karşılık uluslararası toplumu bireylerden oluşan, insanlığın tümü olarak kabul eden görüş, uluslararası hukuku, çeşitli siyasal toplumlara bağlı, bireylerin 
tek başlarına ya da topluca giriştikleri ilişkilerin uluslararası düzeyde düzenlenmesi olarak tanımlamaktadır (Pazarcı, 1983: 2). Uluslararası hukuk, devletler arasında bağlayıcıdır. Ancak, devletler için bu bağlayıcı olma özelliğinin her zaman geçerli olmadığı açıktır. Bugün en önemli sorun, kurallara devletin kendisi uymadığı zaman buna yaptırımının nasıl olacağı ve yaptırımın kimin tarafından sağlanacağıdır. Uluslararası nitelikte mahkeme kararları da uluslararası hukukun gelişmesine önemli katkı sağlamaktadır. Bu gelişmenin her şeyden önce devletlerin yapmış oldukları antlaşmalar sonucunda ortaya çıktığını unutmamak gerekir. Yine de, çevreye ilişkin sorunların uluslararası düzeyde mahkemelere konu olması, çevre hukukunun önemli bir aşama kat ettiğini göstergesidir. Çevre konusunun uluslararası nitelikteki mahkemelere konu olmasının ilk örneklerinden biri, 1974 yılından beri geçerli olan İsveç, Norveç, Danimarka ve Finlandiya arasındaki uygulamadır. Bu gelişmeler çerçevesinde bazı ülkeler, kirliliğe uğrayan ülke vatandaşlarının, ülkenin yargı sistemi içinde, zararın giderilmesi için gerekli hukuki yollara başvurmasına olanak tanımıştır. (Pazarcı, 1983: 204). Uluslararası mahkeme kararlarından, Trail Smelter Davası, Lac Lanoux Davası, Korfu Kanalı Davası, Torrey Canyon Gemisinin Bombalanması Davası önemli örnekler oluşturmaktadır (Kılıç, 2001:135; Ertan, 2004:379). Bu davalar şu sonuçları ortaya çıkmıştır: Her şeyden önce ülke sınırları dışında ortaya çıkan kirliliğin yol açtığı zararlardan, kirliliğe neden olan ülkenin sorumlu olduğu kabul edilmiştir. Böylece kirlilik nedeni ile zarara uğrayan ülke, diğer ülkelerden, meydana gelen zararları giderme ve onarma hakkını elde etmiştir. Diğer yandan, uluslararası alanda sorunlara karşı duyarlıığın artması ile devletin egemenlik anlayışı, daha dar bir biçimde yorumlanmaya başlamıştır. Devletlerin mutlak egemenlik anlayışı giderek daha fazla sınırlandırılarak, devletler arasında hakem rolü oynayabilecek bir gücün varlığı kabul edilir olmuştur (Pazarcı, 1989: 387). Çevreyle ilgili uluslararası sorumluluk anlayışı önemli ölçüde değişmiştir. Ulusların birbirine karşı sorumluluğu konusunda ilk zamanlar kasıt koşulu aranırken, artık kusur koşulu aranmaya başlamıştır. Önce, devletin yaptığı eylem ve işlemlerden dolayı, başka bir devletin zarar görmesi halinde, 
kusura dayalı bir sorumluluk anlayışı ile "kusur sorumluluğu" aranmıştır. Daha sonra ise, uluslararası hukuka aykırı her davranıştan ülkelerin sorumlu tutulması anlayışı egemen duruma gelmiştir (Pazarcı, 1989: 385). Bugün, devletin sorumlu olabilmesi için, zararın çıkması yeterlidir. Çevre sorunlarının sınır aşan özelliğinden dolayı bugün daha çok kusursuz sorumluluk ilkesi geçerlidir. Ayrıca, uluslararası mahkemelerin aldıkları kararların bağlayıcı olması da, çevre hukukunun gelişmesine önemli bir katkı sağlamıştır.

$\mathrm{Bu}$ doğrultuda, çevreye karşı işlenen çevre suçlarının bir ulus sınırını aşıp küreselleşmesi durumunda uluslararasılaşma söz konusu olmaktadır. Bu tür faaliyetler, ulusal sınırların aşılması veya küresel çaplı etki yapması durumunda uluslararası çevre suçu olarak nitelenir. Uluslararası çevre suçu, çevreye yönelik zararlı faaliyetlerin ulusal sınırları aşması, etkilerinin küresel çaplı olması sonucunda oluşan suça denmektedir. Uluslararası çevre suçu kavramı, uluslararası alanda çevreye ilişkin yasa ve düzenlemelere yönelik ihlal durumlarıdır. Sorunun boyutu basit bir ihlalin ötesine geçmektedir, daha ağırdır (Kaya ve Ertürk, 2008:88). Bununla birlikte, çok taraflı çevre anlaşmalarının ilgili suçların denetiminde başarılı olması, anlaşmaların gücüne ve etkin bir şekilde uygulanmasına bağııdır. Bir kere, çok taraflı çevre anlaşmalarının sayısı arttıkça, bu tür suçların da sayısı artmıştır. Bu tür anlaşmalar bu suçları çekici hale de getirmişlerdir. Çevre açısından duyarlı ürünlerin yasadışı ticaretinde görülen büyüme, bu suçları önlemeye yönelik olarak hazırlanmış çevre anlaşmalarının zayıflığından, yetersiz uygulanmasından veya taraf devletlerin uygulamaya ilişkin sorunları nedeniyle yeterince etkin olamamalarından kaynaklanmaktadır (Kaya ve Ertürk, 2008:85). Uluslararası çevre suçları farklı şekil ve tarzlarda ortaya çıkabilmektedir ve bu suçların takibi, soruşturma ve cezalandırmasını içeren süreç eksikliklerle doludur. Gelişmekte olan hükümetlerin bu sözleşmelerin gereğini yerine getirecek altyapıdan yoksun olmaları suçun denetimini güçleştirmektedir. Sözleşmelerin uygulanmasında görülen yerel zafiyetler, uygulamayı güçleştirmektedir. Giderek yaygınlaşan ve uluslararası yasadışı uyuşturucu ve silah kaçakçılığından sonraki en önemli suç olan uluslararası 
çevre suçları, küresel çapta etkiler yaratabilen son derece önemli bir sorun olmasına rağmen denetimleri büyük ölçüde yetersiz kalmaktadır. Bu tür anlaşmaların çözüm aşamasında da yetersiz kaldığı görülmektedir. Yani, uluslararası antlaşmalar bile, çevre koruma açısından değerlendirildiğinde çok fazla engelleyici bir özellik göstermemektedir. Yine de, çevre suçlarıyla mücadeleye ilişkin olarak, hem anlaşmaların güçlendirilmesi, hem de taraf devletlerin uygulamaya ilişkin sorunlarının aşılması bağlamında anlaşmayı uygulama kapasitelerini artırmak gerekmektedir (Kaya ve Ertürk, 2008:85).

\section{SONUÇ VE DEĞERLENDIRME}

Çevreye ilişkin hukuk kuralları, ağırıklı olarak insan merkezli bir yaklaşımın sonucu olarak ortaya çıkmıştır. İnsanın varlığı dikkate alınarak, mevcut doğal kaynakların korunması, kirlenenlerin iyileştirilmesi ve asıl olarak kirlenmeden önlem alınması ilkesi üzerine kurulmuştur. Bu anlayış hem iç hukukta, hem de uluslararası alanda kendini hissettirmiştir. Ancak bütün iyiniyetli çabalara rağmen, çevre sorunlarının önlenmesinde henüz istenilen sonuca ulaşılamamış, tam tersi küresel çevre sorunları daha da ağırlaşmıştır. Özellikle uluslararası düzeyde devletlere çok esnek bir hareket alanının bırakılması, antlaşmalardan ayrılma olanağının tanınması, çevre sorunlarının çözümünde gönüllülük ilkesinin kurulması gibi nedenler sorunun ağırlaşmasında önemli etkenler olmuşlardır. Sonuçta çevreye ilişkin pek çok hukuksal düzenleme yapılmasına karşın, yine de çevre sorunları katlanarak artmıştır ve artmaya devam etmektedir. Böylece dünya ekolojik bir krizin eşiğine gelmiştir.

Bu bağlamda, çevre hukukunun genel olarak kabul görmesi, büyük ölçüde ulusal devletlerin tutumuna bağlıdır. Çünkü, gerek ulusal mevzuatın, gerekse uluslararası sözleşmelerin yapılması ve ulus üstü egemenliklerin tanınması devletlerin iradesine bırakılmıştır. Çevre hukukunun bütün ülkelerde kabul görmesi, aynı zamanda, zengin gelişmiş ülkelerinin, gelişmekte olan ülkeleri ekonomik ve teknik açıdan 
desteklemesine de bağlı bulunmaktadır. Gelişmekte olan ülkeler, nüfuslarını geçindirebilecek ekonomik kaynak yaratamayınca, önce insan ve karın doyurma deyip çevreyi tahrip edebilmektedirler. Bu nedenle, kaynak sıkıntısı içinde bulunan ülkelerin, çevre değerlerini koruyan uluslararası nitelikteki sözleşmeleri, kısa sürede kabul etmeleri güç olabilmektedir. Gelişmekte olan ülkeler, bu tür bağlayıcı uluslararası sözleşmeleri uygulama zorluğu çekmekte; ama, yine de çözüme katılma yoluna gitmektedirler. Zira, günümüz toplumlarının gelecek kaygısı, bugün de olduğu gibi, gelecekte de yaşanılır bir çevreye sahip olma isteği; çevreyi insanlığın ortak varlığı yapmış ve bundan yararlanma hakkını da bir insan hakkı olarak, ama ortak sorumluluğuyla birlikte getirmiştir.

Sonuç olarak, ulusal düzeyde bir çevre hukukunun etkin olabilmesi için, her şeyden önce çevre değerlerinin uluslararası alanda bütün toplumlara ait olarak görülmesi; çevre değerlerinin yok olması halinde, birkaç ülkeyi değil, bütün insanları bir felaketin beklediğinin kabul edilmesi gerekir. Toplumsal alanda çevre bilinci artarsa, çevreye ilişkin düzenlemeler daha kolay kabul görecektir. Belki o zaman, çevrenin yasal açıdan korunması, yerini çevrenin bütünleşik korunmasına bırakacaktır. Her türlü kurum ve kuruluş, çevre hakkının ülkeler arasında giderek daha fazla tanınmasında; ulusal ve uluslararası alanda çevreye ilişkin hukuk kurallarının oluşmasına ve gelişmesine çeşitli düzeylerde katkı sağlamaktadırlar. Ülkemiz de, insan sağlığının ve onurunun gereksinim duyduğu bir ekolojik ortamı kurmak; toprak, hava, su, bitki ve hayvanları, insan müdahalesinden doğan zararlardan korumak ve insandan kaynaklanan zararları ya da dezavantajlı durumları ortadan kaldırmak istiyorsa bunun gereğini yapmalıdır. Uzun dönemde önemli ekonomik ve çevresel maliyetlerle karşılaşmamak için, çevre hukukunun ulusal ve uluslararası alanda çizdiği yol haritasını takip etmek durumundadır. 


\section{KAYNAKÇA}

Akıncı, M. (1996). Türk çevre hukuku, İzmit: Kocaeli Kitapevi Yayınları.

Algan, N. ve Ayşe K. Dündar (2003). Türkiye'nin çevre konusunda verdiği sözler, Ankara: Türkiye Bilimler Akademisi.

Aybay, A. (1997). Çevre ve Hukuk, Insan, Çevre, Toplum, Der: Ruşen Keleş, İmge Yayınları, Ankara, 309-322.

Brundtland, Gro H. (1987), Report of the World Commission on Environment and Development: Our Common Future, UN Documents Gathering a Body of Global Agreements, 20 March 1987, Oslo.

Budak, S. (2000). Avrupa Birliği ve Türk Çevre Politikası, İstanbul: Büke Yayınları.

Budak, S. (2004). Uluslararası Çevre Düzenlemeleri Bağlamında Politika, Adalet ve Katılım, Çevre Sorunlarına Çağdaş Yaklaşımlar, Edit. Mehmet C.Marın, U. Yıldırım, İstanbul: Beta Basım.

Çevre Bakanlığı (1995). Çevre Bakanlığı Mevzuatı 3. Cilt, Ankara: Çevre Bakanlığı Yayınları.

Çevre Bakanlığı (2002). Sürdürülebilir Kalkınma Dünya Zirvesi Türkiye Ulusal Raporu, Çevre Bakanlığı Yayınları, Ankara, http://www.cevre.gov.tr/hukuk.html, 10.10.2011.

Çevre ve Orman Bakanlığı (2006). Türkiye Cumhuriyeti AB Entegre Uyum Stratejisi (2007-2023), Ankara: Çevre ve Orman Bakanlığı Yayınları.

DPT (2007). Dokuzuncu Kalkınma Planı (2007-2013), Çevre Özel ihtisas Komisyonu Raporu, Yayın No. 2737, Ankara. 
Erdoğan, G. (2009). “Çevre Politikalarının Ulusal ve Uluslararası Hukuk Açısından Değerlendirilmesi ve Çevre Sorunları”, İzmir Barosu Dergisi, Nisan Yıl. 73, Sayı. 2, 2-49.

Ertan, B. (2004). Çevre Hukuku, Çevre Sorunlarına Çağdaş Yaklaşımlar, Edit. Mehmet C.Marın, U. Yıldırım, İstanbul: Beta Basım.

Ertan, B. ve Kıvılcım A. E. (2006). "Avrupa Birliği, Çevre Hukuku ve KKTC", Journal of Cyprus Studies, Kıbrıs.

Ertürk, H. (1996). Çevre Bilimlerine Giriş, Bursa: Uludağ Üniversitesi Yayını.

Görmez, K. (1997). Çevre Sorunları ve Türkiye, Ankara: Gazi Kitabevi.

Güçlü, S. Berrin (2007). "Kyoto Protokolü ve Türkiye'nin Protokol Karşısında Durumu”, http://www.metalurji.org.tr/dergi/142/d142_4851.pdf, 08.12.2007,

Hamamcı, C. (1983). Çevre ve Hukuk, Fehmi Yavuz'a Armağan, Ankara: AÜ. SBF. Yayınları, 239-250.

Hamamcı, C. (1997). Çevrenin Uluslararası Boyutu, Insan, Çevre, Toplum, Der: R. Keleş, Ankara: Imge Yayınları, 394-412.

Jardıns, Joseph R. (2006). Çevre Etiği, Çev: Ruşen Keleş, Ankara: İmge Kitabevi.

Kaboğlu, i. (1996). Çevre Hakkı, Ankara: İmge Yayınları.

Kaplan, A. (1997). Küresel Çevre Sorunları ve Politikaları, Ankara: Mülkiyeliler Birliği Vakfı Yayınları.

Karaman, Z. Toprak (1998). Çevre Yönetimi ve Politikası, İzmir: Anadolu Matbaası Yayını. 
Kaya, Y. ve H. Ertürk (2008). “Uluslararası Çevre Suçlarıyla Mücadele ve Çok Taraflı Çevre Anlaşmalarının Etkinliği”, Uluslararası Hukuk ve Politika, Cilt 4, No: 15, 85-112.

Kaypak, Ş. (2008). "Çevre Sorunlarının Çözümüne Hukukun Katkısı ve Çevre Hukuku" Çanakkale Kenti Çevre Sorunları Sempozyumu Bildiriler Kitabı 5-6 Haziran 2008, Çanakkale Onsekiz Mart Üniversitesi, Çanakkale, 187-204.

Kaypak, Ş. (2009). Kent ve Çevre Sorunları, Basılmış Ders Notları, Mustafa Kemal Üniversitesi, Hatay.

Keleş,

R.

(2006).

"Çevrenin

Uluslararası

Boyutları", http://www.kusatak.org/attachment.doc., 10.10.2011.

Keleş, R. ve C. Hamamcı (1993). Çevrebilim, Ankara: Imge Yayınları.

Keleş, R. ve B. Ertan (2002). Çevre Hukukuna Giriş, Ankara: İmge Yayınları.

Kılıç, S. (2001). “Uluslararası Çevre Hukukunun Gelişimi Üzerine Bir İnceleme”, C.Ü. İktisadi ve İdari Bilimler Dergisi, Cilt 2, Sayı 2, 131-149.

Kula, E. (1994). Economics of Natural Resources, the Environment and Policies, Chapman and Hall, London.

Mert,

H. (2009)

"Türk

Hukukunda

Çevre

Suçları", http://www.yayin.adalet.gov.tr/15_sayi.htm, 14.10.2009.

Özdek, Y. (1993). Çevre Hakkı, Ankara: TODAiE Yayını.

Özlüer, F. (2007). "Sürdürülebilir Kalkınmanın Ekonomi Politiği", http://www.ekolojistler.org, 24.11.2007. 
Pazarcı, H. (1983), Çevre Sorunlarının Uluslararası Boyutları ve Uluslararası Hukuk, Fehmi Yavuz'a Armağan, Ankara: AÜ. SBF. Yayınları, 201-237.

Pazarcı, H. (1989). Uluslararası Hukuk Dersleri, Ankara: AÜ. SBF Yayınları.

Pazarcı, H. (1991). Avrupa Topluluğu'nda ve Türkiye'de Çevre Mevzuatı, Çevre Üzerine, Ankara: Türk Çevre Vakfı Yayınları.

Şahin, Y. (2004). Çevre, Yoksulluk ve Adalet, Çevre Sorunlarına Çağdaş Yaklaşımlar, Edit: Mehmet C.Marın, U. Yıldırım, İstanbul: Beta Basım.

Turgut, N. (2001). Çevre Hukuku, 2. Baskı, Ankara: Savaş Yayınevi.

Türkiye Çevre Vakfı (2001). Avrupa Birliğinde ve Türkiye'de Çevre Mevzuatı, Çevre Vakfı Yayını, Ankara: Önder Matbaası.

Ulueren, M. (2001). “Küresel Isınma BM İklim Değişikliği Çerçeve Sözleşmesi ve Kyoto Protokolü", Uluslararası Ekonomik Sorunlar Dergisi, Dış İşleri Bakanlığı Yayınları, 3, Eylül 2001, 38-48

Ulusoy, D. Ali (Tarihsiz). “Çevre Kirlenmesinin Oluşmasından Sonraki Aşamada Medeni Hukuk, Ceza Hukuku ve İdare Hukuku Çözümlerine Genel Bir Bakış", http://dergiler.ankara.edu.tr//38/299/2804.pdf, 126-142

UNEP (2006). "Guidelines on Compliance With And Enforcement of Multilateral Environmental Agreements", http://www.unep.org. 12.10.2011.

Ünder, H. (1996). Çevre Felsefesi: Etik ve Metafizik Görüşler, Ankara: Doruk Yayıncılık.

Ültanır, Mustafa Ö. (2005). “iklim Değişikliği Çerçeve Sözleşmesi”, http://www.ressiad.org.tr/makaleler.php?ID=300, 5.10.2008. 
Ürkmez, T. (2005). "Hukuk ve Çevre", CEKÜD, E-Dergi, http://www.cekud.org/site/page.asp?dsy, 12.04.2008.

Ürkmez, T. (2006). "Çevre Hakkı Kavramının Tarihsel Gelişimi”, http://www.cekud.org/site/page.asp?dsy_id=888, 12.04.2008.

Yaşamış, F. D. (1995). Çevre Yönetiminin Temel Araçları, Ankara: İmge Yayınları.

Yılmaz, Ş. (2009). “Çevre Suçları", http://www.ceza-bb.adalet.gov.tr, 15.07.2009

Yıkılmaz, N. (2003). Yeni Dünya Düzeni ve Çevre, İstanbul: Sosyal Araştırmalar Vakfı Yayınları.

http://www.cevreorman.gov.tr/hukuk.html.

http://www.cevrehukuk.org.

http://www.tmmob.org.tr/genel/bizden_detay.php?kod=3210\&tipi=16 